\title{
Rocky Intertidal Resources Monitoring Handbook, Cabrillo National Monument, Point Loma, San Diego, California
}

By John M. Engle ${ }^{1}$ and Gary E. Davis ${ }^{2}$

U.S. GEOLOGICAL SURVEY

Open-File Report 00-202

Prepared for:

Cabrillo Historical Association

Cabrillo National Monument

Point Loma, California

${ }^{1} 7554$ Palos Verdes Drive

Goleta, California 93117

${ }^{2}$ National Biological Service

Channel Islands National Park

1901 Spinnaker Drive

Ventura, California 93001

Sacramento, California

2000 


\title{
U.S. DEPARTMENT OF THE INTERIOR BRUCE BABBITT, Secretary
}

\author{
U.S. GEOLOGICAL SURVEY \\ Charles G. Groat, Director
}

The use of firm, trade, and brand names in this report is for identification purposes only and does not constitute endorsement by the U.S. Geological Survey

For additional information write to:

Center Director

Western Ecological Research Center

U.S. Geological Survey

Placer Hall, Suite 2012

$6000 \mathrm{~J}$ Street

Sacramento, CA 95819-6129
Copies of this report can be purchased from:

U.S. Geological Survey

Information Services

Box 25286

Federal Center

Denver, CO 80225 


\section{Table of Contents}

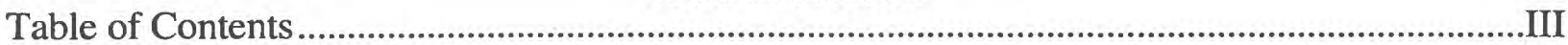

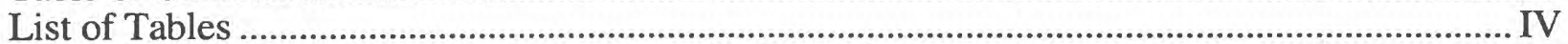

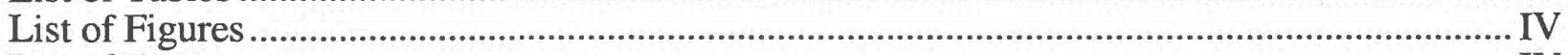

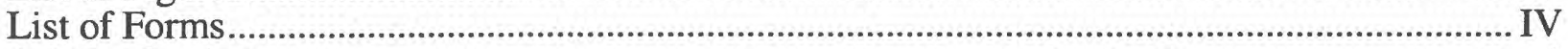

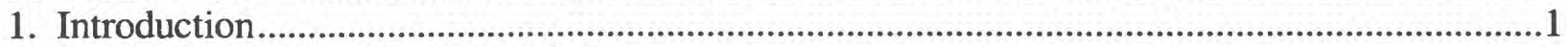

2. Survey Background and Planning..................................................................................

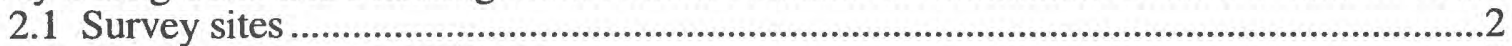

2.2 Target species assemblages....................................................................................

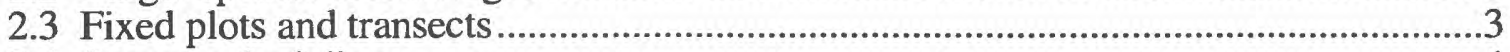

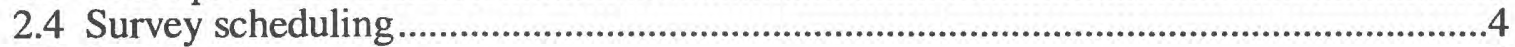

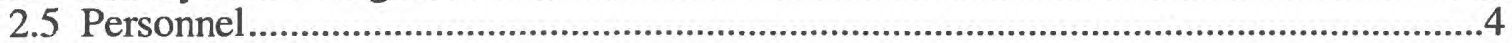

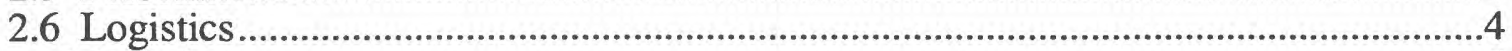

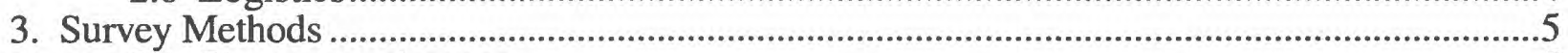

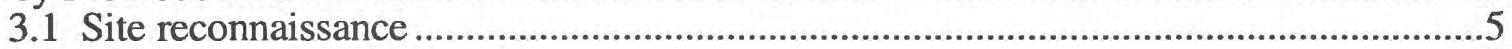

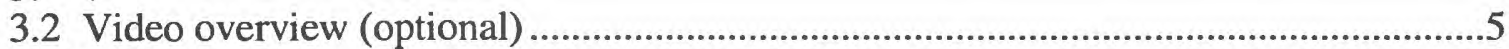

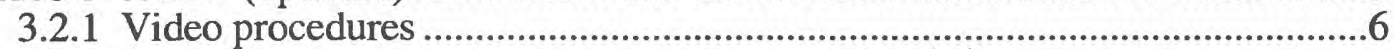

3.2.2 Guidelines for best video results ..........................................................

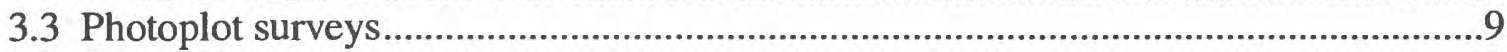

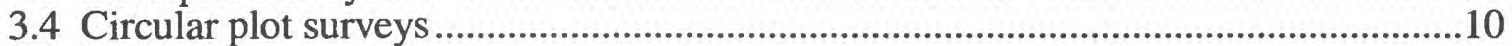

3.5 Line intercept transect surveys....................................................................... 10

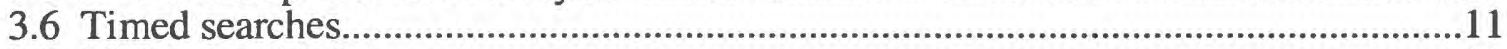

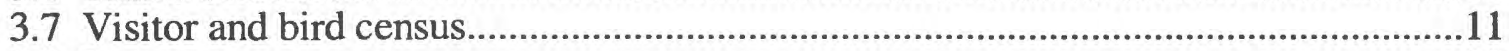

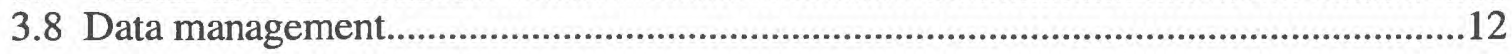




\section{List of Tables}

Table 1. Index Taxa and Monitoring Techniques at Cabrillo National Monument Sites..............13

Table 2. Rocky Intertidal Monitoring Plots and Plot Identification Codes ...................................14

Table 3. Rocky Intertidal Survey Tasks.............................................................................15

Table 4. Area I Rocky Intertidal Interplot Measurements ........................................................16

Table 5. Area II Rocky Intertidal Interplot Measurements.........................................................17

Table 6. Area III Rocky Intertidal Interplot Measurements ....................................................18

List of Figures
Figure 1. Point Loma Rocky Intertidal Monitoring Sites ......................................................19

Figure 2. Visitor Use and Intertidal Monitoring Areas in Cabrillo National Monument .............20

Figure 3. Cabrillo National Monument Area I Map ................................................................21

Figure 4. Cabrillo National Monument Area II Map..............................................................22

Figure 5. Cabrillo National Monument Area III North Map................................................23

Figure 6. Cabrillo National Monument Area III South Map ...................................................24

Figure 7. Photoplot Quadrapod Apparatus ............................................................................25

Form 1. Rocky Intertidal Interplot Measurements ...........................................................26

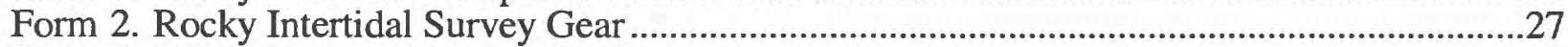

Form 3. Rocky Intertidal Monitoring Field Log ..................................................................28

Form 4. Rocky Intertidal Monitoring Photo Log ...................................................................29

Form 5 Rocky Intertidal Monitoring Owl Limpet Measurements .............................................30

Form 6. Rocky Intertidal Monitoring Line Transect Data ....................................................31

Form 7. Rocky Intertidal Abalone/Sea Star Counts ...............................................................32

Form 8. Rocky Intertidal Monitoring People and Bird Census...................................................33

Form 9. Rocky Intertidal Monitoring Photo Point Intercept Scores ...........................................34 


\section{Introduction}

Long-term monitoring of biological resources and public use in rocky intertidal habitats at Cabrillo National Monument was initiated in 1990 in order to assess dynamic ecological conditions with respect to impacts from public visitation and other human activities in the San Diego metropolitan area. Public access to the monument's intertidal zone is restricted to a single point on the western coast of Point Loma approximately $800 \mathrm{~m}$ north of the tip of the peninsula (Figs. 1 \& 2). From this point, visitors can explore about $1 \mathrm{~km}$ of open ocean shoreline without crossing deep channels that extend to the base of steep cliffs, or moving around the southern tip of the Point into San Diego Bay. This situation creates an apparent gradient of public use extending from the access location downcoast to the Point. The resource monitoring stations were stratified into 3 areas along this presumed human use gradient, with each area encompassing roughly $330 \mathrm{~m}$ of shoreline (Fig. 2). Each of the survey locations, designated Area I, Area II, and Area III (Figs. 1 \& 2), have been monitored semi-annually (Spring and Fall) for the past 6 yr. Two sites north of the Monument, Navy North and South (Fig. 1), have been monitored in 1995 using the same techniques. A separate manual has been developed for the Navy sites. Continued monitoring of all 5 sites in future years is highly recommended. Biological surveys at these locations provide quantitative seasonal data for index species in fixed plots or transects, and qualitative inventory data for other plants and animals whenever possible. In addition, Cabrillo National Monument personnel collect data on prevailing sea/weather conditions and abundances of birds and visitors at the Monument sites whenever possible during daytime low tide periods.

This handbook provides guidelines and specifies procedures for monitoring target species assemblages at Area I, Area II And Area III rocky intertidal sites at the Cabrillo National Monument, Point Loma, San Diego. The handbook will help survey teams prepare for surveys, locate the permanent study plots and standardize sampling procedures for future surveys at these sites, either for continued seasonal monitoring or for impact prevention or assessment studies should the need arise. Visitor and bird census methods and survey data management techniques also are described.

\section{Survey Background and Planning}

This section provides background information about the survey sites, target species, and fixed plots. Survey planning activities are discussed, including scheduling, personnel, and logistical considerations. The guidelines are based on practical experience with intertidal monitoring surveys and field conditions encountered at the Cabrillo National Monument sites since 1990. The guidelines should not be applied rigidly because each survey has its particular circumstances (e.g., weather conditions, number and experience of samplers). Individual judgments will always be necessary in conducting field surveys. It is important to maintain flexibility because unforeseen situations may require last-minute modifications to sampling plans. 


\subsection{Survey sites}

The 3 survey sites (Area I, Area II, Area III) are located on the southernmost outer coast of Point Loma (Figs. 1 \& 2). These, approximately equal-sized sites ( $330 \mathrm{~m}$ long each) are contiguous, extending downcoast along the cliff-backed rocky intertidal shore from the sole beach entry point (Area I) to the southern tip of the peninsula at the Lighthouse (Area III). Access to all 3 sites is via a short trail from the visitor parking lot, located immediately north of the old Navy dolphin training facilities. To get to the parking lot, drive south along Cabrillo Memorial Drive (Route 209), turn right just before reaching the kiosk for the Cabrillo National Monument visitor center, head down the steep road which curves past the lighthouse, and turn left into the parking lot just past the fenced-in Navy compound. Directions for getting to the sites and brief descriptions of physical conditions at the survey locations are as follows:

\section{Area I}

From the visitor parking lot, take the path leading upcoast to the cliff edge. Follow the edge of the cliff to the left (south) and walk down to the intertidal through an area of irregularlysloping bedrock. Area I extends from $\sim 220 \mathrm{~m}$ north to $\sim 110 \mathrm{~m}$ south of the access point (Figs. 2 \& 3). The northern portion of Area I is backed by fractured low cliffs with small caves and pockets of cobble and boulders. Goose barnacle plots and half of the owl limpet plots are located on the steeply sloping base of the sandstone cliffs. The offshore area is composed of pools, surge channels, scattered boulders and gently sloping rock reefs extending 20 to $40 \mathrm{~m}$ from the cliffs. Fixed survey spots are scattered throughout this region, with plots on the raised, mostly granitic boulders and transects on the flat sedimentary reefs. The southern part of the site is in a cove backed by a high cliff and beach. Several transects are located at the north end of this cove (out from the visitor access point), but no monitoring plots are located within the cove. The downcoast boundary of Area I is the south end of the cove.

\section{Area II}

Follow the same directions given above to reach Area I, then hike south along the shore approximately $110 \mathrm{~m}$ to the northern edge of Area II (Figs. 2 \& 4). The hike to Area II takes about 10 min from the parking lot, and is best done when the tide level is $<1 \mathrm{~m}$ above MLLW (in order to avoid getting wet above the waist). Area II extends downcoast approximately $330 \mathrm{~m}$ from the boundary of Area I, with the central portion located offshore from the old Navy dolphin training compound. The northern section of Area II has sloping rock slabs and low-relief reefs, mixed with various-sized boulder/bedrock outcrops. The central and southern parts of the site are backed by an irregular low sandstone cliff with caves and pockets of boulders and cobbles. The lower intertidal zone extends more than $50 \mathrm{~m}$ offshore in Area II, encompassing extensive pools and flat reefs topped with occasional boulders. Fixed survey spots are scattered throughout the site, with goose barnacle and half the owl limpet plots on cliff walls or bases, other plots on boulders, and transects on low-relief bedrock. The southern boundary of Area II is offshore from the Radio Tower.

\section{Area III}

Follow the same directions given above to reach Area II, then continue south approximately $330 \mathrm{~m}$ to the northern end of Area III (Figs. 2, 5-6). The hike to Area III takes 15$20 \mathrm{~min}$ from the parking lot, and also is best done when the tide level is $<1 \mathrm{~m}$ above MLLW. The site extends another $330 \mathrm{~m}$ from the northern edge south to the tip of Point Loma, including a 
prominent line of boulders that extend offshore southwest of the lighthouse. The site is backed by large riprap boulders and a low cliff. Except for the south end boulders, the offshore portion of Area III has extensive, broad, $(>70 \mathrm{~m}$ ) flat reefs with shallow pools and small rocks. The transects for monitoring algal turf, surf grass and boa kelp are located in the northern part of the site. Permanent plots for monitoring goose barnacles are located on granitic riprap boulders placed along the cliff base to reduce erosion. Two acorn barnacle plots are located on a platform in the middle of the site, and one owl limpet plot is located nearby on a bedrock shelf at the base of a cliff point. All of the other permanent plots are located on the line of boulders at the south end of the site (Fig. 6).

\subsection{Target species assemblages}

Key species and broader taxonomic categories surveyed at the Cabrillo National Monument rocky intertidal sites are listed in Table 1. The same 13 target taxa are monitored at each location. Grouped according to survey method, they are as follows:

- Photoplots: acorn, thatched, and goose barnacles, rockweed, and mussels

- Circular plots: owl limpets

- Line transects: boa kelp, sargassum weed, algal turf, surf grass, and anemones

- Timed search: abalone and sea stars

\subsection{Fixed plots and transects}

Table 1 summarizes the sampling techniques and number of plots and transects for each key species at the 3 monitoring sites. The plots and transects have been monitored semi-annually since 1990. There are 5 replicates for each photoplot species, except for goose barnacles which have 6 because monitoring was changed from 3 band transects to 6 photoplots ( 2 per transect) in 1995. Owl limpet plots have 6 replicates, 3 on cliff bases and 3 on boulders, except for Area III which has 5 on boulders and 1 on the only cliff base habitat available. There are 2 replicates for each line-intercept species.

The relatively permanent fixed plots and transects were established at the Monument sites in Spring 1990. The 4 corners of each rectangular photoplot (except for goose barnacles) are marked with $\sim 5 \mathrm{~cm}$ diameter blobs of green epoxy. Photoplot numbers are located at the upper left corner of each plot on a brass tag or etched into the epoxy. Stainless steel or silicone bronze bolts ( $3 / 8$ in) fixed into the bedrock with epoxy were used to mark the corners of goose barnacle photoplots, center of circular owl limpet plots, and start, middle and end, of all transects. Some of the hexagonal bolt heads are marked (using a band saw or hack saw) with notches on the bolt head edge or with grooves across the bolt head top to identify the plot or transect number. Bolt head number codes based on notch and groove combinations are illustrated in Table 2. For plots with notched bolts, the number bolt is located in the upper left corner of each photoplot (with a blank bolt on the other corners), at the center of each circular plot, and at the start (north end) of each transect. Transect center bolts are blank; end bolts are marked "X". Two types of codes are used to identify plots (see Table 2 \& Figs. 3-6). Alphanumeric codes indicate which key species and replicate number is targeted, with the number of bolt notches representing the replicate number. Unique 1-3 digit numeric plot/transect codes were imprinted on the original brass tags (most of which now are missing or unreadable), and continue to be used, especially on bolt-less plots and when shooting plot photographs. Measurements (distance and bearing) taken from the number corner or bolt of each plot/transect to one or more other number corners or bolts are used 
for mapping the sites (Tables 3-5; Form 1), locating hard to find plots/transects, and as standard photo or video reference viewpoints.

\subsection{Survey scheduling}

The sites are sampled semi-annually, in Spring and Fall. Allow 1 day per site, working during the lowest tide $\pm 2-3 \mathrm{hr}$ (4-5 hr total time/sample). The sampling period can be scheduled tentatively months in advance by checking the appropriate San Diego tide table booklet, calendar, or computer program. If possible, survey the sites during the lowest ("spring tide") daylight tide conditions in the months of March/April and October/November. At these times, the best low tides will occur in the afternoons. Generally, there are 5 to 7 workable days within each optimum tidal series. When planning the sampling schedule, remember to take into account factors such as:

- advance arrangements for all participants (transportation, lodging, etc.)

- the time of low tide with respect to sunset (to allow time to complete the site)

- the extra time (at low water) needed to hike to Area III (15-20 min each way)

- some days may not be workable due to rain, wind, or heavy swells.

- 1-2 days at the end of each tidal series should be reserved as "fall-back" days, in case a site survey must be rescheduled.

\subsection{Personnel}

The number of people needed to sample a site depends on level of experience. Four experienced people can sample a site adequately during 1 good low tide period of 4-5 hr; however 6 people, with at least 3 experienced, is recommended. Then it is possible to have 3 teams of 2. Each team should consist of at least 1 sampler who is familiar with that task's techniques and a recorder, who may or may not be experienced. In general there should be separate teams for the plot photographs, owl limpet measurements, and transect scoring. Other tasks to split among the teams include plot/transect location, cleaning/repair of all markers, site reconnaissance, timed search for abalone and sea stars, and video overview (optional).

\subsection{Logistics}

An outline of tasks to be accomplished prior to, during, and after the field sampling is provided in Table 3. Equipment and materials needed for the monitoring should be stored in 1 location so that they can be assembled efficiently prior to each survey trip. It is important to use the Equipment Checklist (Form 1) to be sure nothing is forgotten. Expendable items such as film, batteries, and videotape need to be purchased in advance. Film and batteries can be purchased in bulk and stored in a refrigerator. Spares should be included in case something does not work or gets dropped into a tidepool. Rechargeable batteries should be freshly charged. Load and test camera, strobe, and camcorder to be sure they are working properly. Photocopy required data sheets from originals at the back of the handbook (see Form 1 for recommended number of copies). Required data forms include Field Logs (Form 3), Photo Logs (Form 4), Owl Limpet Measurements (Form 5), Line-Transect Scores (Form 6), Abalone/Sea Star Counts (Form 7), and People/Bird Census Sheets (Form 8). Bring a supply of sharpened \#2 pencils. Remind the data recorders to print legibly and darkly so that the completed data sheets can be photocopied. 
Usually each person carries a backpack or bucket loaded with sampling and personal gear. Five or more rectangular quadrat frames can bundled together with bungee cords or Velcro straps for ease of carrying. Samplers should be prepared for all possible weather conditions (especially sun and wind) and should dress accordingly. Listen to the marine weather and surf reports for current sea conditions. Rubber boots may be worn; however, rugged neopreme booties or old sports shoes work quite well and are easier to walk in when filled with sea water. A spare change of clothing can be useful. Foam gardening pads provide comfort for kneeling during owl limpet measurements. Food, water, a hat, sunglasses, and sunscreen are all recommended.

Transportation time should be planned to arrive at the site anywhere from $2-3 \mathrm{hr}$ before low tide. This includes driving, gear organizing, and hiking time. Allow extra time on the first day for initial equipment setup and orientation of survey participants.

Much of the work should be done as the tide is going out. Generally the tide will be in the mid to late-afternoon, thus approaching darkness will limit work during the rising tide. The target species are best sampled during an out-going tide in this order:

1) High intertidal: goose barnacles, owl limpets, rockweed

2) Mid intertidal: acorn and thatched barnacles, mussels, turf, anemones

3) Low intertidal: sargassum weed, surf grass, boa kelp, abalone, sea stars

\section{Survey Methods}

\subsection{Site reconnaissance}

During each survey it is important to observe and record the general physical and biological conditions at the site. These observations, along with any photo and video overviews, provide valuable perspective on site dynamics which assist in the interpretation of data from the fixed plots and transects. Often it is most practical to do at least part of the site reconnaissance upon first arrival (assuming a descending tide) because many of these observations can be done before the tide is low enough for performing other tasks. Additional notes can be added later during the monitoring, or even afterwards, when more time is available to organize thoughts.

Site reconnaissance notes are recorded on the Field Log (Form 3). Physical conditions to be noted include weather conditions (cloud cover, wind speed and direction, air temperature), sea conditions (wave height and direction, surge, water temperature), substrate changes (sand/gravel burial or scouring, overturned boulders, landslides, etc.), presence and distribution of oil/tar, and other unusual occurrences such as floating debris or pollutants. Biological features that should be recorded include obvious changes (or lack thereof) in target and other species distribution, abundance, recruitment, and appearance (size, color, behavior, epiphytes, etc.). The behavior of birds and people is of interest. Signs of disturbance by visitors may be evident.

\subsection{Video overview (optional)}

Videotape overviews, along with still photographs, document the general physical and biological characteristics of a survey site. They also record plot and transect conditions within the context of the entire site. If desired, they can be used to monitor large-scale temporal changes in biological assemblages. Audio tracks on the videotape allow site reconnaissance observations to be recorded along with the video images. 
A videotape record of each survey site should be made during the initial survey and anytime an obvious change or impact has occurred. If time and personnel permit, video overviews can also be done during routine monitoring surveys. The video operator uses a portable camcorder protected by a splashproof housing to document the nature of conditions at each site through visual recordings on $8 \mathrm{~mm}$ tape accompanied by observational narration. Video views range from distant overviews of general habitat features to close-ups of individual species. Important conditions to document on video include the following: all survey plots and transects, sand influence (beach level, scour or smothering effects), health of organisms (bleached plants, dead barnacles, etc.), interesting concentrations of species, recruitment events, extent of ephemeral algae, oil/tar presence and extent, evidence of people use and/or pollution, and any unusual phenomena.

\subsubsection{Video procedures}

Video procedures for each site consist of the following:

- a broad overview of the entire site if possible from a high cliff vantage point

- a beach level overview of all plots and surrounding habitats from fixed points

- beach level closer views of interesting phenomena

The video documentation can be accomplished by a single experienced person (who knows how to use the equipment, the layout of the study site, and what to document visually and through narration). However, the process becomes most efficient if an assistant is available, because that person can carry supplies (batteries, tapes, maps, etc.), keep track of the sequence of video views, and look out for waves that may splash the video operator and camcorder. The time it takes to do a video survey depends on the spatial extent and complexity of the study site, and the thoroughness of the site documentation. Preliminary reconnaissance prior to actual videotaping is needed to evaluate conditions at the site and organize points to emphasize visually and verbally. This may take 30-60 min and can be done as the tide recedes. The video survey typically takes $1-2 \mathrm{hr}$ around the time of low tide. This includes about 30-60 min of actual videotaping and 30-60 min of other activities, including set-up at each view point, movement between view points, and changing batteries or tapes. Thus the entire video survey operation at one site takes approximately 1.5 to $3 \mathrm{hrs}$ to complete.

Prior to each video survey, the equipment should be assembled and tested. Video camcorders can be finicky (especially Hi-8). Charge all batteries, clean the video head (if necessary), and make a test recording. Review the camcorder operation, the site-specific video plan, and the results of any previous video surveys (so you know what conditions and possible resource changes to look for). At the site, as the tide recedes, locate and mark all plots with bright materials (PVC frames for photoplots, flagging for owl limpet plots, and meter tapes for irregular plots and transects). Conduct an observational reconnaissance of the entire study site -plots, species, etc. Plan the order (and sometimes modified locations) of video views based on sea conditions, tide levels, and sun position. Organize thoughts for narration during videotaping. Set up camcorder and record a title sequence listing study site and survey date. Also at this time, or at the start of the first overview sequence, verbally record the study site, date, video operator, current time, time and height of low tide, weather conditions, and other pertinent information. 
Generally the cliff overview (if present) will be the first video sequence recorded. It puts the entire study site in perspective and documents large-scale changes (e.g., variations in sand levels). Best results are obtained when the tide is fairly low and the plots and reference bolts have been marked conspicuously. Establish a fixed view point, which may be marked or simply described. Use standardized operating procedures and verbal descriptions (see guidelines below). If possible, always start facing upcoast, then use wide-angle view to pan downcoast along the most offshore exposed portion of intertidal first. Reverse the pan for the next closer inshore view. Continue this procedure until the entire shore has been documented. During these video pans, zoom in on key reef areas or survey plots where appropriate, but do not overuse the zoom. All pan and zoom movements should be made slowly.

Beach level overviews are used to put the individual permanent plots or transects into perspective with surrounding assemblages. Record a video sequence from each designated vantage point. At most reference points, plan to do a circular pan $\left(360^{\circ}\right)$ beginning with the most upcoast view. Start with wide angle of more distant habitats on the first pan. If necessary, do a second circular pan of the closest habitats. At any time you can zoom in and describe particular marked plots or other interesting phenomena. It is not necessary to show great detail for each photoplot because the still photos cover that. If particular plots are not covered by video sequences from the marked vantage points, then each plot or group of plots should be videotaped from a standard unmarked view point, usually from about $3 \mathrm{~m}$ away with the sun at your back. For each transect not covered by sequences from the marked vantage points, stand about $3 \mathrm{~m}$ away from the center bolt (with sun at back), then pan slowly along the meter tape from the start bolt to the end bolt. For irregular plots, choose a central vantage point about $3 \mathrm{~m}$ off the plot (with sun at back if possible), then pan along farthest view of plot (starting upcoast and inshore if possible). Reverse the pan for next closer view and continue until the whole plot has been covered.

Close view video sequences of interesting intertidal phenomena not necessarily associated with the survey plots may be recorded if time permits. These need not be done from fixed vantage points, nor do they have to be taped during each succeeding survey at a particular site. If they are important enough to be repeatedly documented, then vantage points should be marked or described for standardization.

\subsubsection{Guidelines for best video results}

\section{Camcorder guidelimes}

These guidelines are for Sony, Nikon, or Ricoh Hi-8 camcorders. Read the manual and know how to operate the camera properly to obtain the best quality video and sound recordings. Camcorders can be sensitive to jarring. Carry in a padded case whenever possible. Check the camera housing lens periodically for salt spray outside (especially on windy days) or fogging inside. These conditions will cause blurred images. If necessary, clean the lens with fresh water or lens cleaner, then wipe dry with lens paper. Insert several small desiccant packs inside the splashproof housing to remove moisture.

Hi-8 tape cassettes provide the highest resolution; however, they are more expensive than regular $8 \mathrm{~mm}$ tapes, cannot be played back on standard $8 \mathrm{~mm}$ camcorders, and require a special monitor to take advantage of the increased resolution. If the drawbacks of $\mathrm{Hi}-8$ tapes present a problem, regular $8 \mathrm{~mm}$ tapes can be used and still provide good quality. $60 \mathrm{~min}$ cassettes are 
preferred, but 120 min tapes also work well. Take 2 fully-charged heavy duty camcorder batteries to ensure up to $1 \mathrm{hr}$ of taping. These batteries never give as much time as expected (especially with lots of zooming), and older batteries do not hold a charge well. Use the video head cleaner tape periodically, especially if the recorded image becomes jittery. Plan to clean the head before each series of intertidal video surveys.

Leave the time display on the video for all recording. This provides a fixed visual record on the tape for later reference. This is especially important if tapes are played on a VCR with a different type of counter than that used when the video log was transcribed. It would be preferable to record both date and time, but most camcorders allow only one or the other.

\section{Video guidelimes}

Tape a title sequence (with the site name and date on a piece of paper) at the start of each video survey and at the beginning of each new tape. Try to videotape at the lowest tide and best light conditions (closest to midday). Unfortunately, many of the good low tides occur in the late afternoon when the sun is low in the sky directly offshore. Best results are obtained under these conditions by keeping the sun behind you as much as possible and by aiming the camera down to reduce the amount of bright sky in view. This helps to minimize under-exposure of shaded reef areas (silhouette effects).

Hold camera as steady as possible, especially when zoomed in. Remain fixed on still shots for several seconds -- longer than seems sufficient while filming. Pan very slowly. You need to consciously slow down any movements. Slow motion pans work much better than walking while taping. Note that your eye (not looking through the eyepiece) generally can see more detail (bolts, tags, etc.) than shows up on the video, especially when contrast is low. On the other hand, videotapes played back on a color monitor appear much better than what you see through the black and white eyepiece monitor. Sometimes, when looking through the small eyepiece, it is difficult to tell if the camera is aimed correctly at low contrast subjects.

\section{Narration guidelimes}

It is not easy to videotape intertidal areas and verbally describe them at the same time. Therefore, it is important to explore the survey site before taping in order to plan what to emphasize and how to describe it. Remember to set the microphone switch to the wind setting. Talk loudly when it is windy or there is noisy surf. At the start and end of each site video (and each tape) and periodically throughout the tape, verbally identify the site, date, time, narrator, and any other pertinent information. Wait several seconds after starting a new tape before talking to be sure what is said will be recorded.

Describe the vantage point at the start of each video sequence. Use standard descriptors for view directions, plot locations, etc. For example, be clear about using "view from" and "view of" when describing a scene. Compass directions may be confusing because local shores can be quite irregular. Instead use "upcoast", "downcoast", "inshore", and "offshore" to describe plot locations and views. Consult the site map before starting each video sequence so that correct plot numbers will be included in the commentary. 


\subsection{Photoplot surveys}

To survey photoquadrats, first locate them using information from the site map, interplot measurement table, and plot print photographs. Clean the corner markers and note their condition, especially whether repairs are needed. Place a temporary 50 X $75 \mathrm{~cm}$ PVC quadrat frame over each plot to mark it for easy relocation, or tie red flagging on bolts . Next, check the camera and strobe (film and batteries loaded?) and assemble the quadrapod apparatus, which holds the camera and strobe directly above each photoplot (Fig. 7). Carry the quadrapod to each plot, replace the temporary PVC frame with the quadrapod so that the photo identification tag is in the upper left corner, adjust the 3 photo identification rings so that each plot number digit appears to the right of each ring, and photograph the plot twice, bracketing for best exposure.

Tide conditions dictate the order in which the quadrats are sampled. If the tide is receding, sample the highest plots, then work down the beach as lower plots are exposed. If the tide is around the low, begin with the downshore plots first. The photographer's assistant must reposition the photo identification tag with the correct plot number each time the frame is placed over a new plot. The assistant also records pertinent information such as photo number, plot number, and exposure on the Photo Log (Form 4). It can be difficult to identify certain species when looking at the slides back in the lab, so it is advisable to jot down (or sketch) a few notes about species composition, cover, unusual or occasional species, etc. while at the plot. After all plot photos are taken, any spare frames left on the roll are used for more general overview shots, or of those species that are not directly targeted by photos (e.g., surf grass, boa kelp, owl limpets).

The procedures described here are for a generic $35 \mathrm{~mm}$, single lens reflex camera, with a $28 \mathrm{~mm}$ lens. Other cameras may be used, but the details of setup and alignment will be slightly different. Use a strobe mounted to the camera to fill in shadows, even in bright sunlight. Read the user manuals for both camera and strobe. Most cameras synchronize focal plane shutters with strobes at a 1/125 second shutter speed. Use that shutter speed with 100 ASA Ektachrome color slide film and aperture settings of $\mathrm{f} 11$ and $\mathrm{f} 16$. This film, at these settings, provides the broad range of image densities required to interpret the photographs in the laboratory. Certainly other films and settings will work, but the recommended settings have proven effective for recording intertidal plots over a wide range of conditions for more than 10 years.

Check all camera gear before leaving for field sampling, while you have no tide-driven time constraints. Use a protective case for the camera, cable shutter release, strobe, film, and spare batteries. Also include lens paper and cleaner, or a chamois skin, a smudge-proof marking pen (sharpie) for marking exposed film rolls, and a lens cap. Bundle the quadrapod components with bungee cords for convenient carrying. Camera Setup

Load the camera in accordance with the manufacturer's instructions. Check camera and strobe batteries to assure full charges. Having to wait for a slow strobe to recharge, or having to replace a camera battery, during a rapidly rising tide is annoying, and leads to haste-induced errors. 


\section{Quadrapod setup}

At the field site, assemble the quadrapod apparatus (Fig. 7). Make sure the PVC rods are securely attached and the frames are parallel by placing the plot frame on a flat surface and pressing firmly on the camera frame fittings. Mount the camera and strobe using a quick release camera mount and the camera's hot shoe. Attach the cable shutter release. Check frame alignment and camera focus by looking through the viewfinder. Adjust the frame as necessary by pressing on the quadrapod fittings. Set the focus at about $0.8 \mathrm{~m}$; you should be able to clearly read the frame number indicator. Set the shutter speed to $1 / 125$ second and the aperture to 11 . Turn on the strobe.

\section{Photographing the plots}

Select the plot to be photographed. Set the plot number indicator rings on the quadrapod plot frame so that the plot numbers are immediately to the right of the rings. Place the quadrapod plot frame over the plot with the plot indicator tag in the upper left corner of the frame. Check frame alignment and focus through the view finder; adjust as necessary. Trip the shutter, check to assure that the strobe discharged, record the plot number and camera settings on the Photo Log (Form 4). If the strobe failed, check the equipment and re-take the picture, recording the failure on the Photo Log. Set the lens aperture at $\mathrm{f} 16$ and repeat the process. Move to the next plot and repeat the process until all plots at the site have been recorded.

\subsection{Circular plot surveys}

Two persons work best for surveying the owl limpet plots: 1 experienced person to identify and measure the limpets, and an assistant to record the data. First locate the plots, using information from the site maps, the interplot measurement chart, and the plot print photos. Clean the markers and note their condition, particularly whether repairs are needed. This is important since there is only one bolt per plot. Tie bright surveyor's flagging to each bolt for ease of relocation. To survey each plot, attach a $1 \mathrm{~m}$ length of line (or meter tape) to the center bolt and swing around in an arc, carefully searching all cracks and crevices for Lottia. Be aware that the limpets may be covered with barnacles, algae, etc., and can even be confused with chitons. Owl limpets found within that arc (including those touched by the $1 \mathrm{~m}$ mark) are measured with calipers to the nearest millimeter, then marked with a yellow forestry crayon to avoid duplicate scoring. However, limpets $<15 \mathrm{~mm}$ are not scored because it is difficult to distinguish tiny Lottia from other species of limpets. Measurements are recorded on the Owl Limpet Data Sheet by a helper (Form 5). If the limpet cannot be measured in place (due to crevices or other irregularities), estimate its size and note this on the data sheet. Never remove limpets from the rock. Observations including obvious scars from missing limpets and any evidence of predation also should be included on the data sheet.

\subsection{Line intercept transect surveys}

Two persons are most efficient for surveying the point-intercept transects, 1 experienced person to identify the organisms located along the tape edge, and an assistant to record the data. First locate the transects, using information from the site maps, the interplot measurement chart, and the transect print photos. Care must be taken not to disturb the positions of plants along the transect path when searching for bolts. Clean the markers and note their condition, particularly whether repairs are needed. Tie bright surveyor's flagging to each bolt for ease of transect relocation. Once the tide is low enough, run a meter tape (again with care) the length of the 
transect, starting from the notched bolt. Watch for approaching surges that might disturb the position of the tape or the plants around it. If possible, survey the entire transect during a period when the tape and plants are undisturbed. To score the line-intercept transects, the sampler walks along each transact, calling out whatever taxon falls directly beneath the tape edge. The line cover estimates are rounded off to the nearest centimeter, thus 1000 separate segments are scored for each $10 \mathrm{~m}$ transect. It may appear as if the scoring would be extremely tedious; however, in practice, relatively few taxa make up most of the line-intercept cover. Up to 8 taxonomic categories are called out by the scorer and then recorded onto the Line-Transect Data Sheet by an assistant (Form 6). Typical scoring may proceed as follows: "bare substrate $0-46 \mathrm{~cm}$, surf grass 46-321 cm, boa kelp 321-378 cm, etc." General observations, such as key species condition (e.g., color and length) and sand cover (if any) are all important to note.

\subsection{Timed searches}

Around the time of low tide, 1 person should spend $30 \mathrm{~min}$ (or 2 persons $15 \mathrm{~min}$ each) searching crevices and pools along the low intertidal zone haphazardly throughout the site for possible occurrences of black abalone (Haliotis cracherodii) or ochre sea stars (Pisaster ochraceus). In addition, record other related species, including green $(H$. fulgens) and pink ( $H$. corrugata) abalone and bat (Asterina miniata), blue knobby (Pisaster giganteus), and fragile (Astrometis sertulifera) stars. Plan to get wet at least to thigh level as you kneel to look under boulders and ledges. Use a waterproof flashlight if necessary to see into dark areas. Turn over occasional rocks and look for juveniles. Record the number and size $(\mathrm{cm})$ of any abalone or sea stars found. For abalone, measure greatest shell length. For sea stars, measure from the middle of the central disk to the tip of the longest ray. Record results on the Abalone/Sea Star Data Sheet (form 7). Note the presence and condition of any abalone shells seen. Other interesting species observations can be recorded on the Field Log and species inventory list (optional).

\subsection{Visitor and bird census}

Unlike all other sampling which takes place twice per year, the number of people and birds should be recorded (to the extent possible) each day that the low tide falls between 1000 $1600 \mathrm{hrs}$ (PST) and is $<15 \mathrm{~cm}$ above mean lower low water (MLLW). About 120 days meet these conditions during the year. This sampling can be conducted by Cabrillo National Monument staff or volunteers as part of their routine patrols of the shore during low tides when visitors are most likely to be present. The number of people and birds within Areas I, II, and III should be counted within 30 min of the low tide by walking along the shore through the 3 areas. The observer must be familar with the site boundaries (see map in Fig. 2). The observer also must be able to recognize different birds, preferably to species, but at least to 3 ecological categories: wading birds, shore birds, and sea birds. Wading birds include herons and egrets. Shore birds include plovers, willets, tattlers, godwits, whimbrels, turnstones, and sanderlings. Sea birds include gulls, cormorants, and pelicans. People and bird counts plus data on weather and sea conditions are recorded on the People and Bird Census Sheet (Form 8). It is important to fill in the data for all categories on the form. Also, use \#2 pencils and print legibly and darkly so completed data sheets can be interpreted correctly and photocopied. The tick marks for people and bird counts should be summed up for each category to eliminate ambiguity (e.g., does "11" represent 2 tick marks or the number 11 ?). Because the people/bird surveys are done on many days, they also represent a good opportunity to observe changes in intertidal life, disturbances 
(e.g., storms), human impacts, behavior of people or birds, etc. These observations should be recorded on the back of the data sheets.

\subsection{Data management}

After returning from sampling, the data sheets should be organized and checked for completeness and legibility. Field notes should be written up (if not done so already) while thoughts are fresh. It is important to make a list of plot markers that need repairs and to note any ideas for increasing the efficiency of sampling. Data sheets along with field notes are filed into notebooks under each site and sampling period. The film is sent off to be processed. When the slides return, mark them individually with site name, date, species and plot number. Organize the slides by site, target species, and sequential plot number into notebooks filed within plastic slideholder sleeves to await scoring.

For scoring, each slide is projected onto a white board that is marked with a grid of 100 evenly-spaced points. Single taxa beneath each of the 100 points are identified and recorded within the proper category on the Point-Intercept Score Sheet ( 9 categories, Form 9). Photoplot and all other numerical data are then entered into a computer spreadsheet file and saved for later analysis. 
Table 1. Index Taxa and Monitoring Techniques at Cabrillo National Monument Sites. Values in parentheses indicate the number of replicate plots emphasizing those particular species.

\begin{tabular}{|c|c|c|c|}
\hline Technique/Taxa & Dimensions & $\begin{array}{l}\text { Number } \\
\text { Per Area }\end{array}$ & $\begin{array}{l}\text { Total } \\
\text { Sample }\end{array}$ \\
\hline Photoplot & $50 \times 75 \mathrm{~cm}$ & 21 & 63 \\
\hline \multicolumn{4}{|l|}{ Acorn Barnacle } \\
\hline \multicolumn{4}{|l|}{ Chthamalus spp. } \\
\hline Pink Thatched Barnacle & & (5) & \\
\hline \multicolumn{4}{|l|}{ Tetraclita rubescens } \\
\hline Rockweed & & (5) & \\
\hline \multicolumn{4}{|l|}{ Pelvetia fastigiata } \\
\hline California Mussel & & (5) & \\
\hline \multicolumn{4}{|l|}{ Mytilus californianus } \\
\hline Goose Barnacle & & (6) & \\
\hline \multicolumn{4}{|l|}{ Pollicipes polymerus } \\
\hline \multicolumn{4}{|l|}{ Other Plants } \\
\hline \multicolumn{4}{|l|}{ Other Animals } \\
\hline \multicolumn{4}{|l|}{ Tar } \\
\hline Bare Substrate & & & \\
\hline
\end{tabular}

Circular Plot

$1 \mathrm{~m}$ radius

6

18

Owl Limpet

Lottia gigantea

Line Transect

Boa Kelp

Egregia menziesii

Sargassum Weed

Sargassum muticum

Red Algal Turf

Corallina spp. et al.

Surf Grass

Phyllospadix spp.

Aggregating Anemone

Anthopleura elegantissima

Other Biota

Tar

Bare Substrate

Timed Search

30 person-minutes

(2)

Black Abalone

$10 \mathrm{~m}$

18

Haliotis cracherodii

Ochre Sea Star

Pisaster ochraceus 
Table 2. Rocky Intertidal Survey Plots and Plot Identification Codes.

\begin{tabular}{|c|c|c|c|c|}
\hline Plot Typel & Plot & & to/Tag C & \\
\hline Key Species & Code & Area 1 & Area II & Area III \\
\hline Photoplot & & & & \\
\hline Bamacles & B1 & 286 & 247 & 3 \\
\hline & B2 & 299 & 248 & 16 \\
\hline & B3 & 294 & 256 & 29 \\
\hline & B4 & 292 & 259 & 30 \\
\hline & B5 & 293 & 260 & 20 \\
\hline Rockweed & Pe1 & 291 & 249 & 9 \\
\hline (Pelvetia) & $\mathrm{Pe} 2$ & 290 & 251 & 10 \\
\hline & $\mathrm{Pe} 3$ & 295 & 252 & 28 \\
\hline & Pe4 & 288 & 258 & 27 \\
\hline & Pe5 & 287 & 265 & 25 \\
\hline Mussel & $\overline{\mathrm{M} 1}$ & 298 & 245 & 24 \\
\hline & M2 & 297 & 246 & 15 \\
\hline & M3 & 296 & 253 & 14 \\
\hline & M4 & 289 & 254 & 17 \\
\hline & M5 & 285 & 255 & 12 \\
\hline Goose Barnacle & Po1 & $276 N$ & & $269 \mathrm{~N}$ \\
\hline (Pollicipes) & P02 & $276 S$ & $275 C$ & $269 \mathrm{~S}$ \\
\hline & Po3 & $281 \mathrm{~N}$ & $274 N$ & $196 \mathrm{C}$ \\
\hline & P04 & $281 \mathrm{~S}$ & $274 S$ & \\
\hline & Po5 & $278 N$ & & $23 N$ \\
\hline & P06 & & $273 S$ & \\
\hline Circular Plot & & & & \\
\hline OwI Limpet & L1 & 280 & 239 & 13 \\
\hline & L2 & 284 & 243 & 26 \\
\hline & L3 & 283 & 240 & 21 \\
\hline & L4 & 282 & 242 & 17 \\
\hline & L5 & 279 & 266 & 18 \\
\hline & L6 & 277 & 241 & 11 \\
\hline Line Transect & & & & \\
\hline Red Algal Turf & T1 & 237 & 244 & 1 \\
\hline & $T 2$ & 210 & 270 & 8 \\
\hline Surf Grass & G3 & 238 & 267 & 7 \\
\hline & G4 & 211 & 271 & 5 \\
\hline Feather Boa Kelp & K5 & 236 & 268 & 2 \\
\hline & K6 & 212 & 272 & 4 \\
\hline
\end{tabular}

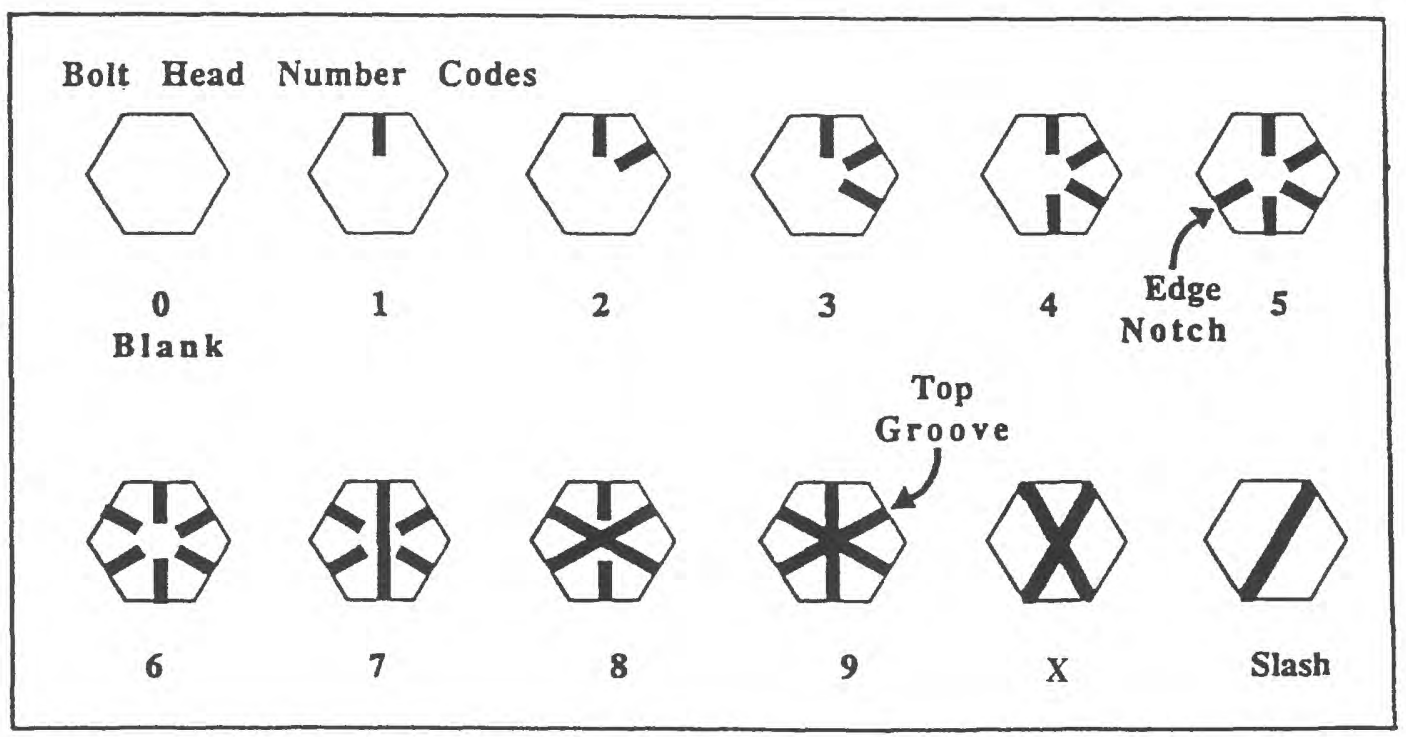


Table 3. Rocky Intertidal Survey Tasks

Prior to surveys

-Organize and test survey gear (see equipment checklist)

-Purchase supplies (film, batteries, videotape)

-Photocopy forms and notes (see equipment checklist)

-Review field procedures and notes from previous surveys

\title{
During Surveys
}

-Site reconnaissance

Evaluate site and complete General Information Sheet

Note observed site conditions

Species list (optional)

Video overview (optional)

-Clean and repair plot markers

-Photoplot surveys

Acorn/Thatched Barnacle Plots

(21 plots at each of 3 sites)

Rockweed Plots

(5)

Mussel Plots

Goose Barnacle Plots

(5)

-Circular Plots

(6 plots at each of 3 sites)

Owl Limpet counts and shell length measurements within $2 \mathrm{~m}$ diameter plots

-Line Transects

Red Algal Turf

(6 transects at each of 3 sites)

Surf Grass

Boa Kelp

-Timed Search

(30 minutes at each of 3 sites)

Abundance and size of abalone and sea stars

-People/Bird Census

(within $30 \mathrm{~min}$ of low tide at each of 3 sites)

\author{
After Surveys \\ -Write up field notes \\ -Organize and check data sheets for completeness and legibility \\ -Process film \\ -Label slides, organize by site and target species \\ -Score slides \\ -Copy videotape to VHS format \\ -Data entry, display and analysis
}


Table 4. CABR I Rocky Intertidal Interplot Measurements.

\begin{tabular}{|l|l|l|l|l|l|l|l|l|l|l|l|l|l|l|l|l|}
\hline FROM & TO & DIST & BEAR & FROM & TO & DIST & BEAR & FROM & TO & DIST & BEAR & & FROM & TO & DIST & BEAR \\
\hline
\end{tabular}

\begin{tabular}{|c|c|c|c|c|c|c|c|c|c|c|c|c|c|c|c|}
\hline 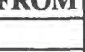 & 20 & (m) & (Mag) & 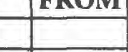 & 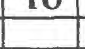 & (m) & (Mag) & 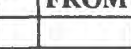 & $\ldots$ & (m) & (Mag) & 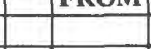 & 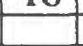 & (m) & (Mag) \\
\hline & & & & & & & & & & & & & & & \\
\hline $210 \mathrm{C}$ & 277 & 15.90 & 45 & $237 \mathrm{~N}$ & $238 \mathrm{~N}$ & 10.10 & 190 & 279 & $281 \mathrm{~S}$ & 9.30 & 310 & 291 & 280 & 13.50 & 85 \\
\hline $210 \mathrm{C}$ & 282 & 10.20 & 290 & $237 \mathrm{~N}$ & $238 \mathrm{~S}$ & 19.20 & 170 & 279 & 287 & 15.00 & 285 & 291 & \begin{tabular}{|l}
284 \\
\end{tabular} & 5.90 & 190 \\
\hline & & & & $237 \mathrm{~N}$ & $276 \mathrm{~N}$ & 17.50 & 145 & 280 & $276 \mathrm{~S}$ & 10.45 & 330 & 291 & 290 & 6.50 & 130 \\
\hline $210 \mathrm{~N}$ & $210 \mathrm{~S}$ & 9.80 & 130 & & & & & 280 & 284 & 14.70 & 240 & 291 & 294 & 19.40 & 310 \\
\hline $210 \mathrm{~N}$ & $211 \mathrm{~N}$ & 17.60 & 100 & $237 \mathrm{~S}$ & $237 \mathrm{~N}$ & 10.05 & 350 & 280 & 290 & \begin{tabular}{|l}
7.90 \\
\end{tabular} & 220 & 291 & \begin{tabular}{|l}
297 \\
\end{tabular} & 22.40 & 320 \\
\hline $210 \mathrm{~N}$ & $211 \mathrm{~S}$ & \begin{tabular}{|l|}
24.10 \\
\end{tabular} & 120 & $237 \mathrm{~S}$ & $238 \mathrm{C}$ & 5.38 & 210 & 280 & 291 & 13.50 & 265 & 291 & 299 & 19.45 & 360 \\
\hline $210 \mathrm{~N}$ & \begin{tabular}{|l|}
277 \\
\end{tabular} & \begin{tabular}{|l|}
17.30 \\
\end{tabular} & 70 & $237 \mathrm{~S}$ & $238 \mathrm{~N}$ & 4.30 & 275 & & & & & & & & \\
\hline $210 \mathrm{~N}$ & 279 & 12.50 & 50 & $237 \mathrm{~S}$ & $238 \mathrm{~S}$ & 9.40 & 190 & $281 \mathrm{~N}$ & $281 S$ & 9.90 & 180 & 292 & 285 & 13.30 & 310 \\
\hline $210 \mathrm{~N}$ & 282 & 6.00 & 270 & $237 \mathrm{~S}$ & $276 \mathrm{~N}$ & 9.60 & 110 & $281 \mathrm{~N}$ & 283 & 15.80 & 250 & 292 & \begin{tabular}{|l|}
288 \\
\end{tabular} & 3.78 & 90 \\
\hline $210 \mathrm{~N}$ & 287 & 12.45 & 330 & $237 \mathrm{~S}$ & 299 & 5.85 & 190 & $281 \mathrm{~N}$ & 287 & 12.42 & 205 & 292 & 295 & 13.55 & 5 \\
\hline & & & & & & & & $281 \mathrm{~N}$ & Po3 & 0.25 & DOW & & & & \\
\hline $210 \mathrm{~S}$ & $210 \mathrm{~N}$ & 9.80 & 310 & $238 \mathrm{C}$ & $237 \mathrm{~S}$ & 5.38 & 30 & & & & & 293 & 282 & 9.55 & 180 \\
\hline & & & & $238 \mathrm{C}$ & $238 \mathrm{~N}$ & 4.99 & 345 & $281 \widehat{S}$ & $278 \mathrm{~N}$ & 6.03 & 160 & 293 & \begin{tabular}{|l|}
287 \\
\end{tabular} & 10.30 & 90 \\
\hline $211 \mathrm{C}$ & $211 \mathrm{~N}$ & 5.95 & 345 & $238 \mathrm{C}$ & 286 & $\sim 9.1$ & 360 & $281 \mathrm{~S}$ & 279 & 9.30 & 130 & 293 & 288 & 7.68 & 360 \\
\hline $211 \mathrm{C}$ & $212 \mathrm{~S}$ & 6.28 & 225 & $238 \mathrm{C}$ & 299 & 2.63 & 120 & $281 \mathrm{~S}$ & $281 \mathrm{~N}$ & 9.90 & 360 & & & & \\
\hline & & & & & & & & $281 \mathrm{~S}$ & \begin{tabular}{|l|}
287 \\
\end{tabular} & 7.30 & 255 & 294 & 291 & 19.40 & 130 \\
\hline $211 \mathrm{~N}$ & $210 \mathrm{~N}$ & 17.60 & 280 & $238 \mathrm{~N}$ & $236 \mathrm{~N}$ & 13.60 & 265 & $281 \mathrm{~S}$ & Po4 & 0.90 & 315 & 294 & \begin{tabular}{|l}
296 \\
\end{tabular} & 14.20 & 225 \\
\hline $211 \mathrm{~N}$ & $211 \mathrm{C}$ & 5.95 & 165 & $238 \mathrm{~N}$ & $236 \mathrm{~S}$ & 16.96 & 240 & & & & & 294 & 297 & 3.28 & 360 \\
\hline $211 \mathrm{~N}$ & $211 \mathrm{~S}$ & 10.00 & 160 & $238 \mathrm{~N}$ & $237 \mathrm{C}$ & 5.97 & 40 & 282 & $210 \mathrm{C}$ & 10.20 & 110 & & & & \\
\hline $211 \mathrm{~N}$ & $212 \mathrm{~N}$ & 11.20 & 255 & $238 \mathrm{~N}$ & $237 \mathrm{~N}$ & 10.10 & 10 & 282 & $210 \mathrm{~N}$ & 6.00 & 90 & 295 & 282 & 27.47 & 175 \\
\hline $211 \mathrm{~N}$ & $212 \mathrm{~S}$ & 10.60 & 180 & $238 \mathrm{~N}$ & $237 \mathrm{~S}$ & 4.30 & 95 & 282 & $212 \mathrm{~N}$ & 14.80 & 120 & 295 & \begin{tabular}{|l}
283 \\
\end{tabular} & 8.95 & 145 \\
\hline $211 \mathrm{~N}$ & 277 & 8.99 & 10 & $238 \mathrm{~N}$ & $238 \mathrm{C}$ & 4.99 & 165 & 282 & $212 \mathrm{~S}$ & 24.80 & 120 & 295 & 285 & 14.95 & 270 \\
\hline $211 \mathrm{~N}$ & $278 \mathrm{~S}$ & 7.50 & 35 & $238 \mathrm{~N}$ & $238 \mathrm{~S}$ & 10.08 & 160 & 282 & 287 & 10.70 & 360 & 295 & 288 & 11.20 & 180 \\
\hline & & & & $238 \mathrm{~N}$ & $276 \mathrm{~N}$ & 13.60 & 105 & 282 & 293 & 9.55 & 360 & 295 & 289 & 26.55 & 290 \\
\hline $211 \mathrm{~S}$ & $210 \mathrm{~N}$ & 24.10 & 300 & $238 \mathrm{~N}$ & 299 & 7.20 & 155 & 282 & 295 & 27.47 & 355 & 295 & 290 & 7.00 & 5 \\
\hline $211 \mathrm{~S}$ & $211 \mathrm{~N}$ & 10.00 & 340 & & & & & & & & & 295 & 292 & 13.55 & 185 \\
\hline $211 \mathrm{~S}$ & $212 \mathrm{C}$ & 9.18 & 275 & $238 \mathrm{~S}$ & $236 \mathrm{C}$ & 16.79 & 280 & 283 & $281 N$ & 15.80 & 70 & & & & \\
\hline 2115 & $212 \mathrm{~N}$ & 14.80 & 285 & $238 \mathrm{~S}$ & $236 \mathrm{~N}$ & 18.94 & 290 & 283 & 287 & 9.85 & 125 & 296 & 284 & 21.05 & 100 \\
\hline $211 \mathrm{~S}$ & $212 \mathrm{~S}$ & 5.80 & 255 & $238 \mathrm{~S}$ & $236 \mathrm{~S}$ & 16.33 & 265 & 283 & 288 & 5.82 & 215 & 296 & 289 & 7.60 & 180 \\
\hline $211 \mathrm{~S}$ & \begin{tabular}{|l|}
277 \\
\end{tabular} & 18.80 & 340 & $238 \mathrm{~S}$ & $237 \mathrm{~N}$ & 19.20 & 350 & 283 & 295 & 8.95 & 325 & 296 & 294 & 14.20 & 45 \\
\hline & & & & $238 \mathrm{~S}$ & $237 \mathrm{~S}$ & 9.40 & 10 & & & & & & & & \\
\hline $212 \mathrm{C}$ & $211 \mathrm{~S}$ & 9.18 & 95 & $238 \mathrm{~S}$ & $238 \mathrm{~N}$ & 10.08 & 340 & 284 & 280 & 14.70 & 60 & 297 & 291 & 22.40 & 140 \\
\hline $212 \mathrm{C}$ & $212 \mathrm{~N}$ & 6.29 & 310 & $238 \mathrm{~S}$ & $276 \mathrm{~N}$ & 10.70 & 55 & 284 & 285 & 13.55 & 215 & 297 & 294 & 3.28 & 180 \\
\hline & & & & $238 \mathrm{~S}$ & $276 \mathrm{~S}$ & 13.60 & 110 & 284 & 289 & 20.50 & 265 & 297 & 298 & 0.80 & 360 \\
\hline $212 \mathrm{~N}$ & $211 N$ & 11.20 & 75 & $238 \mathrm{~S}$ & 299 & 3.55 & 10 & 284 & 290 & 7.27 & 90 & & & & \\
\hline $212 \mathrm{~N}$ & $211 \mathrm{~S}$ & 14.80 & 105 & & & & & 284 & 291 & 5.90 & 10 & 298 & $236 \mathrm{~N}$ & 13.50 & 355 \\
\hline $212 \mathrm{~N}$ & $212 \mathrm{C}$ & 6.29 & 130 & $276 \mathrm{~N}$ & $237 \mathrm{~N}$ & 17.50 & 325 & 284 & 296 & 21.05 & 280 & 298 & $236 \mathrm{~S}$ & 3.76 & 360 \\
\hline $212 \mathrm{~N}$ & $212 \mathrm{~S}$ & 10.19 & 135 & $276 \mathrm{~N}$ & $237 \mathrm{~S}$ & 9.60 & 290 & & & & & 298 & 286 & 23.76 & 60 \\
\hline $212 \mathrm{~N}$ & 277 & 15.80 & 50 & $276 \mathrm{~N}$ & $238 \mathrm{~N}$ & 13.60 & 285 & 285 & 284 & 13.55 & 35 & 298 & 297 & 0.80 & 180 \\
\hline $212 \mathrm{~N}$ & 282 & 14.80 & 300 & $276 \mathrm{~N}$ & $238 \mathrm{~S}$ & 10.70 & 235 & 285 & 289 & 14.60 & 295 & 298 & 299 & 18.65 & 80 \\
\hline & & & & $276 \mathrm{~N}$ & $276 \mathrm{~S}$ & 10.17 & 165 & 285 & 292 & 13.30 & 130 & 298 & REF & 5.78 & 20 \\
\hline $212 \mathrm{~S}$ & $211 \mathrm{C}$ & 6.28 & 45 & $276 \mathrm{~N}$ & 299 & 9.05 & 260 & 285 & 295 & 14.95 & 90 & & & & \\
\hline $212 \mathrm{~S}$ & $211 N$ & 10.60 & 360 & $276 \mathrm{~N}$ & Pol & & & & & & & 299 & $237 \mathrm{~S}$ & 5.85 & 10 \\
\hline $212 \mathrm{~S}$ & $211 \mathrm{~S}$ & 5.80 & 75 & & & & & 286 & $236 \mathrm{~N}$ & 15.74 & 275 & 299 & $238 \mathrm{C}$ & 2.63 & 300 \\
\hline $212 \mathrm{~S}$ & $212 \mathrm{~N}$ & 10.19 & 315 & $276 \mathrm{~S}$ & $238 \mathrm{~S}$ & 13.60 & 290 & 286 & $238 \mathrm{C}$ & -9.1 & 180 & 299 & $238 \mathrm{~N}$ & 7.20 & 335 \\
\hline $212 \mathrm{~S}$ & 277 & 19.10 & 360 & $276 \mathrm{~S}$ & $276 \mathrm{~N}$ & 10.17 & 345 & 286 & 298 & 23.76 & 240 & 299 & $238 \mathrm{~S}$ & 3.55 & 190 \\
\hline $212 \mathrm{~S}$ & 282 & 24.80 & 300 & $276 S$ & 280 & 10.45 & 150 & 286 & 299 & 10.73 & 180 & 299 & $276 \mathrm{~N}$ & 9.05 & 80 \\
\hline & & & & $276 \mathrm{~S}$ & 299 & 14.70 & 305 & & & & & 299 & $276 \mathrm{~S}$ & 14.70 & 125 \\
\hline $236 \mathrm{C}$ & $236 \mathrm{~N}$ & 5.03 & 355 & $276 \mathrm{~S}$ & Po2 & & & 287 & $210 \mathrm{~N}$ & 12.45 & 150 & 299 & 286 & 10.73 & 360 \\
\hline $236 \mathrm{C}$ & $238 \mathrm{~S}$ & 16.79 & 100 & & & & & 287 & 279 & 15.00 & 105 & 299 & 291 & 19.45 & 180 \\
\hline & & & & 277 & $210 \mathrm{C}$ & 15.90 & 225 & 287 & $281 \mathrm{~N}$ & 12.42 & 25 & 299 & 298 & 18.65 & 260 \\
\hline $236 \mathrm{~N}$ & $236 \mathrm{C}$ & 5.03 & 175 & 277 & $210 \mathrm{~N}$ & 17.30 & 250 & 287 & $281 \mathrm{~S}$ & 7.30 & 75 & & & & \\
\hline $236 \mathrm{~N}$ & $236 \mathrm{~S}$ & 9.90 & 175 & 277 & $211 \mathrm{~N}$ & 8.99 & 190 & 287 & 282 & 10.70 & 180 & REF & $236 \mathrm{~N}$ & 8.27 & 350 \\
\hline $236 \mathrm{~N}$ & $238 \mathrm{~N}$ & 13.60 & 85 & 277 & $211 \mathrm{~S}$ & 18.80 & 160 & 287 & 283 & 9.85 & 303 & REF & $236 \mathrm{~S}$ & 2.70 & 225 \\
\hline $236 \mathrm{~N}$ & $238 \mathrm{~S}$ & 18.94 & 110 & 277 & $212 \mathrm{~N}$ & 15.80 & 230 & 287 & 293 & 10.30 & 270 & REF & 298 & 5.78 & 200 \\
\hline $236 \mathrm{~N}$ & 286 & 15.74 & 95 & 277 & $212 \mathrm{~S}$ & 19.10 & 180 & & & & & & & & \\
\hline $236 \mathrm{~N}$ & 298 & 13.5 & 175 & 277 & 278 & 3.10 & 335 & 288 & 283 & 5.82 & 35 & \#TAG & $236 \mathrm{~N}$ & 2.34 & 210 \\
\hline $236 \mathrm{~N}$ & REF & 8.27 & 170 & 277 & 279 & 8.08 & 300 & 288 & 292 & 3.78 & 270 & & & & \\
\hline $236 \mathrm{~N}$ & \#TAG & 2.34 & 30 & 277 & Po6 & 0.76 & 25 & 288 & 293 & 7.68 & 180 & Pol & $276 \mathrm{~N}$ & & \\
\hline & & & & & & & & 288 & 295 & 11.20 & 360 & Pol & Po2 & & \\
\hline $236 \mathrm{~S}$ & $236 \mathrm{~N}$ & 9.90 & 355 & $278 \mathrm{~N}$ & 277 & 3.10 & 155 & & & & & Po2 & Pol & & \\
\hline $236 \mathrm{~S}$ & $23 \overline{8 N}$ & 16.96 & 60 & $278 \mathrm{~N}$ & 279 & 6.00 & 275 & 289 & 284 & 20.50 & 85 & Po2 & $276 \mathrm{~S}$ & & \\
\hline $236 \mathrm{~S}$ & $238 \mathrm{~S}$ & 16.33 & 85 & $278 \mathrm{~N}$ & $281 \mathrm{~s}$ & 6.03 & 340 & 289 & 285 & 14.60 & 115 & Po3 & P04 & 8.89 & -175 \\
\hline $236 \mathrm{~S}$ & 298 & 3.76 & 180 & $278 \mathrm{~N}$ & P05 & 0.27 & 55 & 289 & 295 & 26.55 & 110 & Po3 & $281 \mathrm{~N}$ & 0.25 & UP \\
\hline $236 \mathrm{~S}$ & REF & 2.70 & 45 & & & & & 289 & 296 & 7.60 & 360 & Po4 & $281 \mathrm{~S}$ & 0.9 & 135 \\
\hline & & & & $278 \mathrm{~S}$ & $211 N$ & 7.50 & 215 & & & & & Po4 & Po3 & 8.89 & -355 \\
\hline $237 \mathrm{C}$ & $238 \mathrm{~N}$ & 5.97 & 220 & & & & & 290 & 280 & 7.90 & 40 & Po5 & Po6 & 2.87 & 155 \\
\hline $237 \mathrm{C}$ & $237 \mathrm{~N}$ & 5.02 & 350 & 279 & $210 \mathrm{~N}$ & 12.50 & 230 & 290 & 284 & 7.27 & 270 & Po5 & $278 \mathrm{~N}$ & 0.27 & 235 \\
\hline $237 \mathrm{~N}$ & $237 \mathrm{C}$ & 5.02 & 170 & 279 & 277 & 8.08 & 120 & 290 & 291 & 6.50 & 310 & Po6 & 277 & 0.76 & 205 \\
\hline $237 \mathrm{~N}$ & $237 \mathrm{~S}$ & 10.05 & 170 & 279 & $278 \mathrm{~N}$ & 6.00 & 95 & 290 & 295 & 7.00 & 185 & Po6 & Po5 & 2.87 & 335 \\
\hline
\end{tabular}


Table 5. CABR II Rocky Intertidal Interplot Measurements.

\begin{tabular}{|c|c|c|c|c|c|c|c|c|c|c|c|c|c|c|c|}
\hline FROM & TO & DIST & BEAR & FROM & TO & DIST & BEAR & FROM & TO & DIST & BEAR & FROM & TO & DIST [ & BEAR \\
\hline & & (m) & (Mag) & & & (m) & (Mag) & & & (m) & (Mag) & & & $(\mathrm{m})$ & (Mag) \\
\hline & & & & & & & & & & & & & & & \\
\hline 239 & $244 C$ & 6.90 & 55 & 251 & 246 & 11.91 & 260 & $268 \mathrm{C}$ & $267 \mathrm{~N}$ & 6.05 & 360 & $272 \mathrm{C}$ & 241 & 24.83 & 150 \\
\hline 239 & $244 N$ & 12.95 & 15 & 251 & 249 & 3.25 & 45 & & & & & $272 \mathrm{C}$ & $271 \mathrm{C}$ & 8.41 & 135 \\
\hline 239 & 244S & 6.91 & 60 & 251 & 252 & 9.54 & 135 & $268 \mathrm{~N}$ & 239 & 15 & 130 & $272 \mathrm{C}$ & 271N & 5.71 & 105 \\
\hline 239 & 248 & 29.10 & 190 & & & & & $268 \mathrm{~N}$ & $267 \mathrm{~N}$ & 1.95 & 90 & $272 \mathrm{C}$ & $271 S$ & 11.93 & 155 \\
\hline 239 & $267 \mathrm{~N}$ & 14.80 & 340 & 252 & 243 & 10.10 & 130 & $268 \mathrm{~N}$ & $268 \mathrm{C}$ & 5.12 & 165 & $272 \mathrm{C}$ & $272 \mathrm{~N}$ & 5.61 & 340 \\
\hline 239 & $267 \mathrm{~S}$ & 5.20 & 290 & 252 & 251 & 9.54 & 315 & $268 \mathrm{~N}$ & $268 \mathrm{~S}$ & 10.1 & 165 & & & & \\
\hline 239 & $268 \mathrm{~N}$ & 15.00 & 310 & 252 & $275 \mathrm{~N}$ & 19.08 & 45 & & & & & $272 N$ & 241 & 30.31 & 155 \\
\hline 239 & $268 \mathrm{~S}$ & 8.08 & 275 & 252 & $275 \mathrm{~S}$ & 12.89 & 55 & $268 \mathrm{~S}$ & 239 & 8.08 & 95 & $272 \mathrm{~N}$ & 255 & 22.38 & 25 \\
\hline \multirow[t]{2}{*}{239} & $275 N$ & 34.07 & 150 & & & & & $268 \mathrm{~S}$ & $267 \mathrm{~N}$ & 10.88 & 350 & $272 N$ & $270 \mathrm{~N}$ & 16.24 & 105 \\
\hline & & & & 253 & 246 & 23.57 & 360 & $268 \mathrm{~S}$ & $267 \mathrm{~S}$ & 3.36 & 75 & $272 \mathrm{~N}$ & $271 \mathrm{C}$ & 13.63 & 145 \\
\hline 240 & 254 & 25.69 & 320 & 253 & 254 & 6.29 & 180 & $268 \mathrm{~S}$ & $268 \mathrm{~N}$ & 10.1 & 345 & $272 \mathrm{~N}$ & $271 \mathrm{~N}$ & 9.58 & 135 \\
\hline 240 & 255 & 26.20 & 290 & 253 & $275 S$ & 27.71 & 50 & & & & & $272 \mathrm{~N}$ & $271 S$ & 17.46 & 155 \\
\hline \multirow[t]{2}{*}{240} & 256 & 12.65 & 180 & & & & & $270 \mathrm{C}$ & 241 & 16.64 & 190 & $272 \mathrm{~N}$ & $272 \mathrm{C}$ & 5.61 & 160 \\
\hline & & & & 254 & 240 & 25.69 & 140 & $270 \mathrm{C}$ & 256 & 17.28 & 60 & $272 \mathrm{~N}$ & $272 \mathrm{~S}$ & 10.46 & 160 \\
\hline 241 & $270 \mathrm{C}$ & 16.64 & 10 & 254 & 253 & 6.29 & 360 & $270 \mathrm{C}$ & 258 & 21.56 & 90 & & & & \\
\hline 241 & $270 \mathrm{~N}$ & 21.70 & 360 & 254 & 255 & 19.65 & 250 & $270 \mathrm{C}$ & $270 \mathrm{~N}$ & 5.44 & 345 & $272 S$ & 241 & 20.10 & 150 \\
\hline 241 & $270 \mathrm{~S}$ & 12.90 & 45 & & & & & $270 \bar{C}$ & $271 \mathrm{C}$ & 9.36 & 260 & $272 \mathrm{~S}$ & $271 \mathrm{C}$ & 4.55 & 105 \\
\hline 241 & $271 \mathrm{C}$ & 16.83 & 335 & 255 & 240 & 26.20 & 110 & $270 \mathrm{C}$ & $271 N$ & 10.40 & 295 & $272 \mathrm{~S}$ & $271 \mathrm{~N}$ & 5.54 & 45 \\
\hline 241 & 271N & 21.70 & 345 & 255 & 254 & 19.65 & 70 & $270 \mathrm{C}$ & $271 \mathrm{~S}$ & 11.16 & 240 & $272 \mathrm{~S}$ & $271 \mathrm{~S}$ & 7.17 & 150 \\
\hline 241 & $271 \mathrm{~S}$ & 12.95 & 320 & 255 & $270 \mathrm{~N}$ & 26.29 & 210 & & & & & $272 \mathrm{~S}$ & $272 \mathrm{~N}$ & 10.46 & 340 \\
\hline 241 & $272 \mathrm{C}$ & 24.83 & 330 & 255 & $271 \mathrm{~N}$ & 26.70 & 185 & $270 \mathrm{~N}$ & 241 & 21.70 & 180 & & & & \\
\hline 241 & $272 \mathrm{~N}$ & 30.31 & 335 & 255 & $272 \mathrm{~N}$ & 22.38 & 205 & $270 \mathrm{~N}$ & 255 & 26.29 & 390 & $273 N$ & 260 & 23.88 & 270 \\
\hline \multirow[t]{2}{*}{241} & $272 S$ & 20.10 & 330 & & & & & $270 \mathrm{~N}$ & 256 & 17.20 & 90 & $273 \mathrm{~N}$ & $274 \mathrm{~S}$ & 14.75 & 340 \\
\hline & & & & 256 & 240 & 12.65 & 360 & $270 \mathrm{~N}$ & 258 & 23.76 & 105 & $273 \mathrm{~N}$ & P05 & 2.52 & -250 \\
\hline 242 & 256 & 21.27 & 260 & 256 & 242 & 21.27 & 80 & $270 \mathrm{~N}$ & $270 \mathrm{C}$ & 5.44 & 165 & & & & \\
\hline 242 & 259 & 11.40 & 220 & 256 & $270 \mathrm{C}$ & 17.28 & 240 & $270 \mathrm{~N}$ & $270 \mathrm{~S}$ & 10.11 & 150 & $273 \mathrm{~S}$ & 260 & 25.96 & 295 \\
\hline 242 & 266 & 10.21 & 155 & 256 & $270 \mathrm{~N}$ & 17.20 & 270 & $270 \mathrm{~N}$ & $271 \mathrm{C}$ & 10.05 & 230 & $273 \mathrm{~S}$ & Po6 & 1.61 & -290 \\
\hline \multirow[t]{2}{*}{242} & $274 \mathrm{~N}$ & 7.63 & 180 & 256 & $270 \mathrm{~S}$ & 17.98 & 225 & $270 \mathrm{~N}$ & $271 \mathrm{~N}$ & 8.19 & 270 & & & & \\
\hline & & & & & & & & $270 \mathrm{~N}$ & \begin{tabular}{|l|}
$271 S$ \\
\end{tabular} & 13.60 & 215 & $274 \mathrm{~N}$ & 242 & 7.63 & 360 \\
\hline 243 & 252 & 10.10 & 310 & 258 & 259 & 5.69 & 110 & $270 \mathrm{~N}$ & $272 \mathrm{~N}$ & 16.24 & 285 & $274 N$ & 259 & 12.00 & 290 \\
\hline \multirow[t]{2}{*}{243} & $275 \mathrm{~S}$ & 12.40 & 355 & 258 & $270 \mathrm{C}$ & 21.56 & 270 & & & & & $274 \mathrm{~N}$ & 265 & 10.60 & 270 \\
\hline & & & & 258 & $270 \mathrm{~N}$ & 23.76 & 285 & $270 \mathrm{~S}$ & 241 & 12.90 & 225 & $274 \mathrm{~N}$ & 266 & 2.80 & 180 \\
\hline $244 \mathrm{C}$ & 239 & 6.90 & 235 & 258 & \begin{tabular}{|l|}
$270 \mathrm{~S}$ \\
\end{tabular} & 19.98 & 260 & $270 \mathrm{~S}$ & 256 & 17.98 & 45 & $274 \mathrm{~N}$ & Po3 & Same p & \\
\hline \multirow[t]{2}{*}{$244 \mathrm{C}$} & 239 & 9.09 & 205 & & & & & $270 \mathrm{~S}$ & 258 & 19.98 & 80 & & & & \\
\hline & & & & 259 & 242 & 11.40 & 40 & $270 \mathrm{~S}$ & $270 \mathrm{~N}$ & 10.11 & 330 & $274 \mathrm{~S}$ & 260 & 13.90 & 270 \\
\hline $244 N$ & 239 & 12.95 & 195 & 259 & 258 & 5.69 & 290 & $270 \mathrm{~S}$ & $271 \mathrm{C}$ & 11.67 & 285 & $274 \mathrm{~S}$ & 266 & 7.10 & NA \\
\hline $244 N$ & $244 C$ & 5.01 & 165 & 259 & 265 & 5.29 & 140 & $270 S$ & $271 \mathrm{~N}$ & 14.20 & 310 & $274 \mathrm{~S}$ & $273 \mathrm{~N}$ & 14.75 & 160 \\
\hline $244 N$ & $244 \mathrm{~S}$ & 9.77 & 160 & 259 & 266 & 12.45 & 100 & $270 \mathrm{~S}$ & 271S & 11.62 & 260 & $274 S$ & Po4 & 0.89 & 305 \\
\hline $244 \mathrm{~N}$ & $267 \mathrm{~N}$ & 12.00 & 290 & 259 & $274 \mathrm{~N}$ & 12.00 & 110 & & & & & & & & \\
\hline & & & & & & & & $271 C$ & 241 & 16.83 & 155 & $275 \mathrm{~N}$ & 239 & 34.07 & 330 \\
\hline $244 S$ & 239 & 6.91 & 240 & 260 & 265 & 10.75 & 10 & $271 C$ & $270 \mathrm{C}$ & 9.36 & 80 & $275 \mathrm{~N}$ & 252 & 19.08 & 225 \\
\hline $244 S$ & $244 \mathrm{~N}$ & 9.77 & 340 & 260 & $273 \mathrm{~N}$ & 23.88 & 90 & $271 \mathrm{C}$ & $270 \mathrm{~N}$ & 10.05 & 50 & $275 \mathrm{~N}$ & Pol & 3.08 & -220 \\
\hline $244 \mathrm{~S}$ & $267 \mathrm{~S}$ & 10.97 & 265 & 260 & $273 \mathrm{~S}$ & 25.96 & 115 & $271 \mathrm{C}$ & $270 \mathrm{~S}$ & 11.67 & 105 & & & & \\
\hline & & & & 260 & $274 \mathrm{~S}$ & 13.90 & 90 & $271 \mathrm{C}$ & $271 N$ & 5.12 & 355 & $275 \mathrm{~S}$ & 243 & 12.40 & 175 \\
\hline 245 & 246 & 9.08 & 160 & & & & & $271 \mathrm{C}$ & $272 \mathrm{C}$ & 8.41 & 315 & $275 \mathrm{~S}$ & 252 & 12.89 & 235 \\
\hline 245 & 247 & 9.09 & 145 & 265 & 259 & 5.29 & 320 & $271 C$ & $272 \mathrm{~N}$ & 13.63 & 325 & $275 \mathrm{~S}$ & 253 & 27.71 & 230 \\
\hline 245 & 248 & 11.85 & 135 & 265 & 260 & 10.75 & 190 & $271 \mathrm{C}$ & $272 \mathrm{~S}$ & 4.55 & 285 & $275 \mathrm{~S}$ & Po2 & 5.57 & 345 \\
\hline & & & & 265 & $274 \mathrm{~N}$ & 10.60 & 90 & & & & & & & & \\
\hline 246 & 245 & 9.08 & 340 & & & & & $271 \mathrm{~N}$ & 241 & 21.70 & 165 & Pol & $275 \mathrm{~N}$ & 3.08 & -40 \\
\hline 246 & 247 & 3.00 & 90 & 266 & 242 & 10.21 & 335 & $271 \mathrm{~N}$ & 255 & 26.70 & 5 & Pol & \begin{tabular}{|l} 
Po2 \\
\end{tabular} & 1.26 & 140 \\
\hline 246 & 251 & 11.91 & 80 & 266 & 259 & 12.45 & 280 & $271 \mathrm{~N}$ & $270 \mathrm{C}$ & $10 . \overline{40}$ & 115 & & & & \\
\hline 246 & 253 & 23.57 & 180 & 266 & $274 \mathrm{~N}$ & 2.80 & 360 & $271 \mathrm{~N}$ & $270 \mathrm{~N}$ & 8.19 & 90 & Po2 & Po1 & 1.26 & 320 \\
\hline & & & & 266 & $274 \mathrm{~S}$ & 7.1 & NA & $271 N$ & $270 \mathrm{~S}$ & 14.20 & 130 & Po2 & $275 \mathrm{~S}$ & 5.57 & 165 \\
\hline 247 & 245 & 9.09 & 325 & & & & & $271 N$ & \begin{tabular}{|l|}
$271 C$ \\
\end{tabular} & 5.12 & 175 & & & & \\
\hline 247 & 246 & 3.00 & 270 & $267 \mathrm{C}$ & $268 \mathrm{~N}$ & 4.93 & 315 & $271 \mathrm{~N}$ & $271 S$ & 9.70 & 180 & Po3 & $274 \mathrm{~N}$ & Same p & \\
\hline 247 & 248 & 5.71 & 90 & & & & & $271 \mathrm{~N}$ & $272 \mathrm{C}$ & 5.71 & 285 & Po3 & Po4 & 8.84 & -170 \\
\hline & & & & $267 \mathrm{~N}$ & 239 & 14.80 & 160 & $271 \mathrm{~N}$ & $272 \mathrm{~N}$ & 9.58 & 315 & & & & \\
\hline 248 & 239 & 29.10 & 10 & $267 \mathrm{~N}$ & $244 \mathrm{~N}$ & 12.00 & 110 & $271 \mathrm{~N}$ & $272 \mathrm{~S}$ & 5.54 & 225 & Po4 & $274 \mathrm{~S}$ & 0.89 & 125 \\
\hline 248 & 245 & 11.85 & 315 & $267 \mathrm{~N}$ & $267 \mathrm{C}$ & 4.97 & 160 & & & & & Po4 & Po3 & 8.84 & -350 \\
\hline 248 & 247 & 5.71 & 270 & $267 \mathrm{~N}$ & $267 \mathrm{~S}$ & 10.65 & 155 & $271 S$ & 241 & 12.95 & 140 & & & & \\
\hline 248 & 249 & 6.55 & 180 & $267 \mathrm{~N}$ & $268 \mathrm{~N}$ & 1.95 & 270 & $271 S$ & $270 \mathrm{C}$ & 11.16 & 60 & Po5 & $273 \mathrm{~N}$ & 2.52 & -70 \\
\hline & & & & $267 \mathrm{~N}$ & $268 \mathrm{~S}$ & 10.88 & 170 & 271S & $270 \mathrm{~N}$ & 13.60 & 35 & Po5 & Po6 & 5.02 & -150 \\
\hline 249 & 248 & 6.55 & 360 & & & & & $271 S$ & $270 \mathrm{~S}$ & 11.62 & 80 & & & & \\
\hline 249 & 251 & 3.25 & 225 & $267 \mathrm{~S}$ & 239 & 5.20 & 110 & $271 S$ & $271 \mathrm{~N}$ & 9.70 & 360 & Po6 & $273 S$ & 1.61 & $\sim 110$ \\
\hline 249 & 252 & 11.44 & 145 & $267 \mathrm{~S}$ & $244 S$ & 10.97 & 85 & $271 S$ & $272 \mathrm{C}$ & 11.93 & 335 & Po6 & \begin{tabular}{|l|} 
Po5 \\
\end{tabular} & 5.02 & -330 \\
\hline & & & & $267 \mathrm{~S}$ & $267 \mathrm{~N}$ & 10.65 & 335 & $271 S$ & $272 \mathrm{~N}$ & 17.46 & 335 & & & & \\
\hline & & & & $267 \mathrm{~S}$ & $268 \mathrm{~S}$ & \begin{tabular}{|l|}
3.36 \\
\end{tabular} & 255 & $271 S$ & $272 \mathrm{~S}$ & 7.17 & 330 & & & & \\
\hline
\end{tabular}


Table 6. CABR III Rocky Intertidal Interplot Measurements.

\begin{tabular}{|c|c|c|c|c|c|c|c|c|c|c|c|c|c|c|c|}
\hline FROM & TO & DIST $]$ & BEAR & FROM & TO & DIST & BEAR & FROM & TO & DIST & $\overline{\text { BEAR }}$ & FROM & TO & DIST & BEAR \\
\hline & & (m) & (Mag.) & & & (m) & (Mag.) & & & (m) & (Mag.) & & & (m) & (Mag.) \\
\hline & & & & & & & & & & & & & & & \\
\hline $01 \mathrm{C}$ & $01 \mathrm{~N}$ & 4.93 & 335 & $05 \mathrm{~S}$ & $01 \mathrm{C}$ & 12.25 & 310 & 14 & 15 & 2.90 & 360 & 29 & 09 & 7.35 & 90 \\
\hline $01 \mathrm{C}$ & $05 \mathrm{~N}$ & 8.22 & 75 & $05 \mathrm{~S}$ & $01 \mathrm{~N}$ & 16.92 & 320 & 14 & 18 & 2.10 & 180 & 29 & $23 \mathrm{~S}$ & 33.75 & 360 \\
\hline $01 \mathrm{C}$ & $05 \mathrm{~S}$ & 12.25 & 130 & $05 \mathrm{~S}$ & $01 \mathrm{~S}$ & 7.88 & 300 & & & & & 29 & 27 & 8.10 & 180 \\
\hline \multirow[t]{2}{*}{$01 \mathrm{C}$} & $07 \mathrm{~N}$ & 20.21 & 55 & $05 \mathrm{~S}$ & $02 \mathrm{~N}$ & 18.80 & 230 & 15 & 14 & 2.90 & 180 & 29 & 30 & 1.95 & 225 \\
\hline & & & & $05 \mathrm{~S}$ & $05 \mathrm{~N}$ & \begin{tabular}{|l|}
10.07 \\
\end{tabular} & 340 & 15 & 19 & 1.50 & 315 & & & & \\
\hline $01 N$ & $01 \mathrm{C}$ & 4.93 & 155 & $05 \mathrm{~S}$ & $07 \mathrm{~N}$ & \begin{tabular}{|l|}
20.22 \\
\end{tabular} & 20 & & & & & 30 & 26 & 17.73 & 160 \\
\hline $01 \mathrm{~N}$ & 015 & 10.06 & 140 & $05 \mathrm{~S}$ & $07 \mathrm{~S}$ & \begin{tabular}{|l|}
12.03 \\
\end{tabular} & 5 & 16 & 03 & 1.55 & 345 & 30 & 27 & 6.60 & 160 \\
\hline $01 \mathrm{~N}$ & $02 \mathrm{~N}$ & 22.60 & 180 & $05 \mathrm{~S}$ & Beach & \begin{tabular}{|l|}
49.61 \\
\end{tabular} & 70 & 16 & 23 & 30.60 & 70 & 30 & 28 & 6.25 & 250 \\
\hline $01 \mathrm{~N}$ & $05 \mathrm{~N}$ & 10.51 & 90 & $05 \mathrm{~S}$ & Outmk & 36.60 & 160 & 16 & 32 & 30.6 & 75 & 30 & 29 & 1.95 & 45 \\
\hline $01 \mathrm{~N}$ & $05 \mathrm{~S}$ & 16.92 & 140 & & & & & & & & & & & & \\
\hline \multirow[t]{2}{*}{ OIN } & $07 \mathrm{~N}$ & 20.45 & 75 & $07 \mathrm{C}$ & $07 \mathrm{~N}$ & 5 & 45 & 17 & 12 & 1.70 & 135 & $269 \mathrm{~N}$ & Beach & 46.50 & 360 \\
\hline & & & & & & & & 17 & 18 & 5.80 & 360 & $269 \mathrm{~N}$ & \begin{tabular}{|l|} 
Innk \\
\end{tabular} & \begin{tabular}{|l|}
49.10 \\
\end{tabular} & 240 \\
\hline 015 & OIN & 10.06 & 320 & $07 \mathrm{~N}$ & $01 \mathrm{C}$ & 20.21 & 235 & & & & & $269 \mathrm{~N}$ & Pol & 1.30 & 140 \\
\hline $01 \mathrm{~S}$ & $02 \mathrm{~N}$ & 15.90 & 200 & $07 \mathrm{~N}$ & $01 \mathrm{~N}$ & 20.45 & 255 & 18 & 14 & 2.10 & 360 & & & & \\
\hline 015 & $05 \mathrm{~N}$ & 8.85 & 40 & $07 \mathrm{~N}$ & 015 & 21.45 & 220 & 18 & 17 & 5.80 & 180 & $269 \mathrm{~S}$ & Inmk & 54.5 & 250 \\
\hline 015 & $05 S$ & 7.88 & 120 & $07 \mathrm{~N}$ & $05 \mathrm{~N}$ & 12.64 & 225 & & & & & $269 \mathrm{~S}$ & $22 \mathrm{~N}$ & \begin{tabular}{|l|}
20.40 \\
\end{tabular} & 180 \\
\hline \multirow[t]{2}{*}{$01 \mathrm{~S}$} & $07 \mathrm{~N}$ & 21.45 & 40 & $07 \mathrm{~N}$ & $05 \mathrm{~S}$ & 20.22 & 200 & 19 & 15 & 1.50 & 135 & & & & \\
\hline & & & & $07 \mathrm{~N}$ & $07 \mathrm{C}$ & 5.00 & 225 & 19 & 20 & 1.82 & 360 & Beach & $05 \mathrm{~N}$ & 48.43 & 260 \\
\hline $02 \mathrm{~N}$ & $01 \mathrm{~N}$ & 22.60 & 360 & $07 \mathrm{~N}$ & $07 \mathrm{~S}$ & 9.87 & 225 & & & & & Beach & $05 \mathrm{~S}$ & 49.61 & 250 \\
\hline $02 \mathrm{~N}$ & $01 \mathrm{~S}$ & 15.90 & 20 & $07 \mathrm{~N}$ & $08 \mathrm{~N}$ & 33.65 & 130 & 20 & 19 & 1.82 & 180 & Beach & $07 \mathrm{~N}$ & 38.72 & 275 \\
\hline $02 \mathrm{~N}$ & 025 & 9.60 & 150 & $07 \mathrm{~N}$ & Beach & \begin{tabular}{|l|}
38.72 \\
\end{tabular} & 95 & 20 & 21 & 1.60 & 360 & Beach & $07 \mathrm{~S}$ & \begin{tabular}{|l}
46.30 \\
\end{tabular} & 260 \\
\hline $02 \mathrm{~N}$ & $04 \mathrm{~N}$ & 19.20 & 180 & & & & & & & & & Beach & $08 \mathrm{C}$ & 30.19 & 205 \\
\hline $02 \mathrm{~N}$ & $05 S$ & 18.80 & 50 & 075 & $05 \mathrm{~N}$ & 2.79 & 220 & 21 & 20 & 1.60 & 180 & Beach & $08 \mathrm{~N}$ & 26.65 & 220 \\
\hline \multirow[t]{2}{*}{$02 \mathrm{~N}$} & Outmk & 33.35 & 180 & $07 \mathrm{~S}$ & $05 \mathrm{~S}$ & 12.03 & 185 & 21 & 24 & \begin{tabular}{|l|l|}
0.74 \\
\end{tabular} & 360 & Beach & $08 \mathrm{~S}$ & 34.14 & 200 \\
\hline & & & & $07 \mathrm{~S}$ & $07 \mathrm{~N}$ & \begin{tabular}{|l|}
9.87 \\
\end{tabular} & 45 & & & & & Beach & $269 \mathrm{~N}$ & 46.50 & 180 \\
\hline $02 \mathrm{~S}$ & $02 \mathrm{~N}$ & 9.60 & 330 & $07 \mathrm{~S}$ & Beach & 46.30 & 80 & $22 \mathrm{~N}$ & $269 \mathrm{~S}$ & 20.40 & 360 & Beach & Inmk & 44.90 & 135 \\
\hline $02 \mathrm{~S}$ & $04 \mathrm{~N}$ & 9.29 & 160 & & & & & & & & & & & & \\
\hline $02 \mathrm{~S}$ & $04 S$ & 19.85 & 225 & $08 \mathrm{C}$ & $08 \mathrm{~N}$ & 4.95 & 345 & $22 \mathrm{~S}$ & 13 & 7.80 & 200 & Inmk & $08 \mathrm{C}$ & 14.74 & 20 \\
\hline \multirow[t]{2}{*}{$02 \mathrm{~S}$} & Outmk & 24.70 & 120 & $08 \mathrm{C}$ & Beach & 30.19 & 25 & & & & & Inmk & $08 \mathrm{~N}$ & 19.05 & 20 \\
\hline & & & & $08 \mathrm{C}$ & Inmk & \begin{tabular}{|l|l}
14.74 \\
\end{tabular} & 200 & 23 & 16 & 30.6 & 255 & Inmk & 085 & \begin{tabular}{|l|l|}
0.95 \\
\end{tabular} & 45 \\
\hline 03 & 13 & \begin{tabular}{|l}
37.10 \\
\end{tabular} & 315 & & & & & 23 & 3 & 30.75 & 250 & Inmk & 269 & \begin{tabular}{|l|l|}
49.10 \\
\end{tabular} & 60 \\
\hline 03 & 16 & 1.55 & 165 & $08 \mathrm{~N}$ & $05 \mathrm{~N}$ & 36.45 & 340 & & & & & Inmk & $269 \mathrm{~S}$ & 54.50 & 70 \\
\hline \multirow[t]{2}{*}{03} & 23 & 30.75 & 70 & $08 \mathrm{~N}$ & $07 \mathrm{~N}$ & \begin{tabular}{|l|l}
33.65 \\
\end{tabular} & 310 & $23 \mathrm{~N}$ & 13 & 59.80 & 340 & Innk & Beach & 44.90 & 315 \\
\hline & & & & $08 \mathrm{~N}$ & $08 \mathrm{C}$ & 4.95 & 165 & $23 \mathrm{~N}$ & 16 & 30.60 & 250 & Inmk & Outmk & 26.30 & 225 \\
\hline $04 \mathrm{C}$ & $04 \mathrm{~N}$ & 5.01 & 350 & $08 \mathrm{~N}$ & 085 & 9.97 & 165 & & & & & & & & \\
\hline \multirow[t]{2}{*}{$04 \mathrm{C}$} & $04 \mathrm{~S}$ & - & 180 & $08 \mathrm{~N}$ & Beach & 26.60 & 68 & $23 \mathrm{~S}$ & 29 & 33.75 & 180 & Outmk & $02 \mathrm{~N}$ & 33.35 & 360 \\
\hline & & & & $08 \mathrm{~N}$ & Beach & 26.65 & 40 & & & & & Outmk & 025 & 24.70 & 300 \\
\hline $04 \mathrm{~N}$ & $02 \mathrm{~N}$ & \begin{tabular}{|l|}
19.20 \\
\end{tabular} & 360 & $08 \mathrm{~N}$ & \begin{tabular}{|l} 
Inmk \\
\end{tabular} & \begin{tabular}{|l}
19.05 \\
\end{tabular} & 200 & 24 & 21 & 0.74 & 180 & Outmk & $04 \mathrm{~N}$ & 16.55 & 340 \\
\hline $04 \mathrm{~N}$ & $02 \mathrm{~S}$ & \begin{tabular}{|l}
9.29 \\
\end{tabular} & 340 & & & & & 24 & 25 & 3.00 & 360 & Outmk & $04 \mathrm{~S}$ & 16.84 & 225 \\
\hline $04 \mathrm{~N}$ & $04 \mathrm{C}$ & 5.01 & 170 & 085 & $08 \mathrm{~N}$ & 9.97 & 345 & & & & & Outmk & $05 \mathrm{~S}$ & 36.60 & 340 \\
\hline $04 \mathrm{~N}$ & $04 \mathrm{~S}$ & \begin{tabular}{|l}
10.74 \\
\end{tabular} & 170 & $08 \mathrm{~S}$ & Beach & 34.14 & 20 & 25 & 24 & 3.00 & 180 & Outmk & Inmk & 26.30 & 45 \\
\hline \multirow[t]{2}{*}{$04 \mathrm{~N}$} & Outmk & 16.55 & 160 & 085 & Inmk & 10.95 & 225 & 25 & 26 & 5.80 & 360 & & & & \\
\hline & & & & & & & & 25 & 27 & 16.40 & 345 & Pol & $269 \mathrm{~N}$ & 1.30 & 320 \\
\hline $04 \mathrm{~S}$ & $02 \mathrm{~S}$ & 19.85 & 45 & 09 & 10 & 3.60 & 90 & & & & & Pol & Po2 & 8.25 & 140 \\
\hline $04 \mathrm{~S}$ & $04 \mathrm{C}$ & 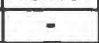 & 360 & 09 & 27 & 7.80 & 225 & 26 & 25 & 5.80 & 180 & & & & \\
\hline $04 \mathrm{~S}$ & $04 \mathrm{~N}$ & \begin{tabular}{|l|}
10.74 \\
\end{tabular} & 350 & 09 & 29 & \begin{tabular}{|l}
7.35 \\
\end{tabular} & 270 & 26 & 27 & 12.20 & 350 & Po2 & Po1 & 8.25 & 320 \\
\hline \multirow[t]{2}{*}{045} & Outmk & 16.84 & 45 & & & & & 26 & 28 & \begin{tabular}{|l|l}
11.65 \\
\end{tabular} & 360 & Po2 & Po3 & 23.80 & 125 \\
\hline & & & & 10 & 09 & 3.60 & 270 & 26 & 30 & 17.73 & 340 & & & & \\
\hline \multirow[t]{2}{*}{$05 \mathrm{C}$} & $05 \mathrm{~N}$ & 5.03 & 340 & & & & & & & & & Po3 & Po2 & 23.80 & 305 \\
\hline & & & & 11 & 12 & 1.70 & 340 & 27 & 09 & 7.80 & 45 & Po3 & Po4 & 3.82 & 125 \\
\hline $05 \mathrm{~N}$ & $01 \mathrm{C}$ & 8.22 & 255 & & & & & 27 & 25 & 16.40 & 165 & & & & \\
\hline $05 \mathrm{~N}$ & $01 \mathrm{~N}$ & 10.51 & 270 & 12 & 11 & 1.70 & 160 & 27 & 26 & 12.20 & 170 & Po4 & Po3 & 3.82 & 305 \\
\hline $05 \mathrm{~N}$ & $01 \mathrm{~S}$ & 8.85 & 220 & 12 & 17 & \begin{tabular}{|l|l}
1.70 \\
\end{tabular} & 315 & 27 & 28 & 2.30 & 245 & Po4 & Po5 & 68.62 & 110 \\
\hline $05 \mathrm{~N}$ & $05 \mathrm{C}$ & 5.03 & 160 & & & & & 27 & 29 & 8.10 & 360 & & & & \\
\hline $05 \mathrm{~N}$ & $05 \mathrm{~S}$ & \begin{tabular}{|l|l}
10.07 \\
\end{tabular} & 160 & 13 & 03 & 37.10 & 135 & 27 & 30 & 6.60 & 340 & P05 & Po4 & 68.62 & 290 \\
\hline $05 \mathrm{~N}$ & $07 \mathrm{~N}$ & 12.64 & 45 & 13 & $22 \mathrm{~S}$ & 7.80 & 20 & & & & & Po5 & Po6 & 1.72 & 170 \\
\hline $05 \mathrm{~N}$ & $07 \mathrm{~S}$ & 2.79 & 40 & 13 & $23 \mathrm{~N}$ & 59.80 & 160 & 28 & 26 & 11.65 & 180 & & & & \\
\hline $05 \mathrm{~N}$ & $08 \mathrm{~N}$ & 36.45 & 160 & & & & & 28 & 27 & 2.30 & 65 & Po6 & P05 & 1.72 & 350 \\
\hline $05 \mathrm{~N}$ & Beach & 48.43 & 80 & & & & & 28 & 30 & \begin{tabular}{|l|}
6.25 \\
\end{tabular} & 70 & & & & \\
\hline
\end{tabular}


Fig. 1. Point Loma Rocky Intertidal Monitoring Sites.

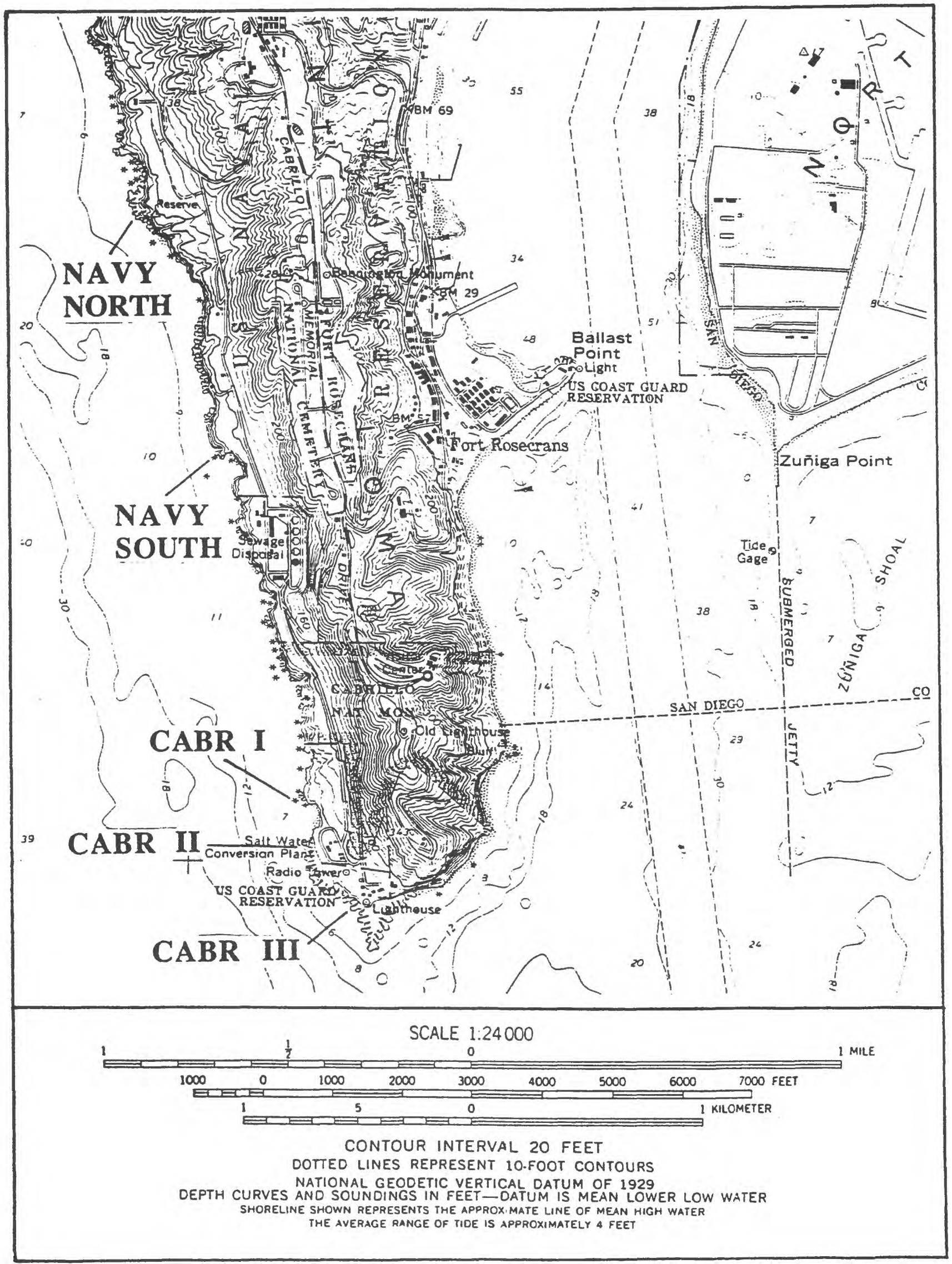


Figure 2. Intertidal Visitor Use and Ecological Monitoring Areas in Cabrillo NM.

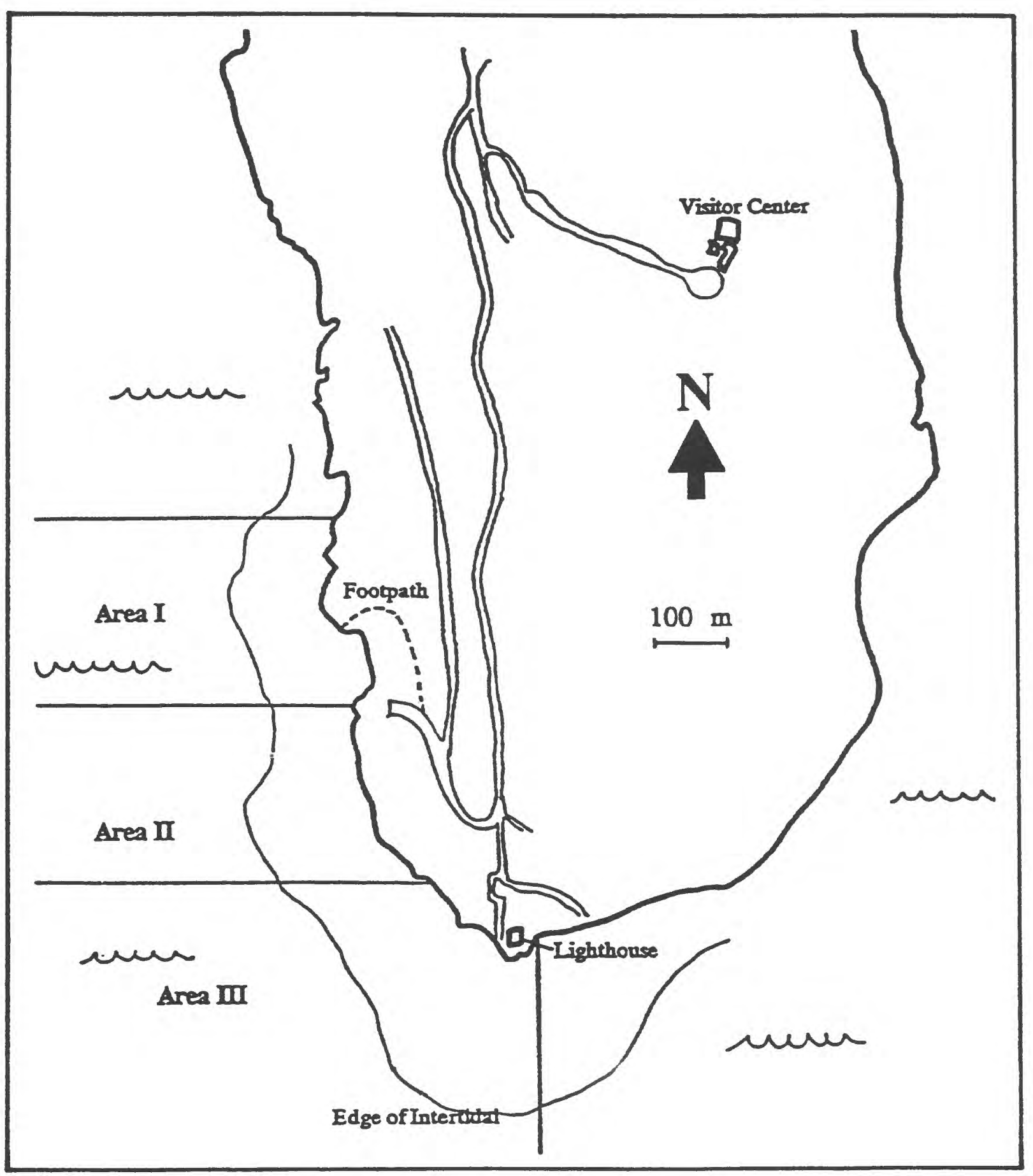


Fig. 3. Cabrillo National Monument Area I Map.

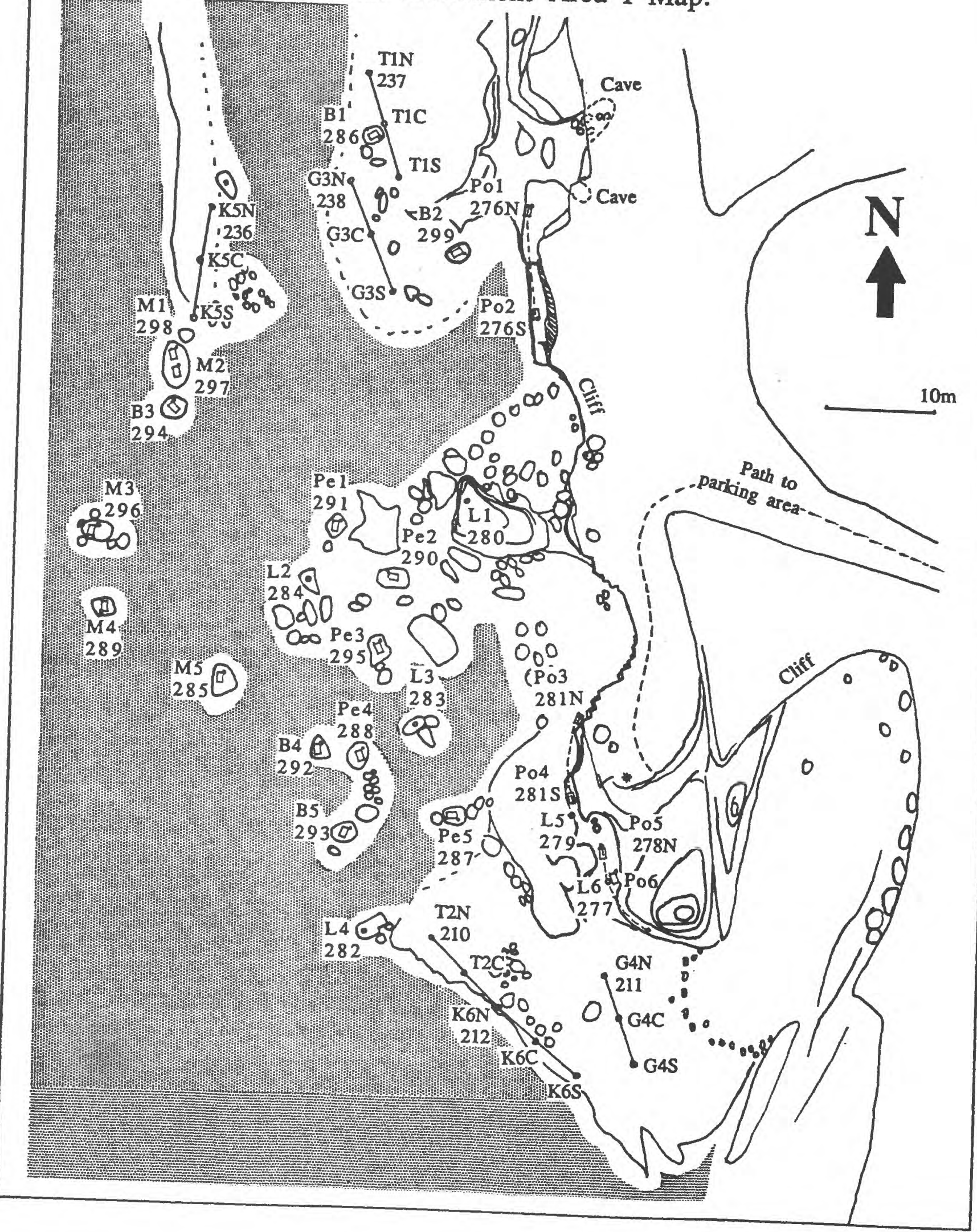


Fig. 4. Cabrillo National Monument Area II Map.

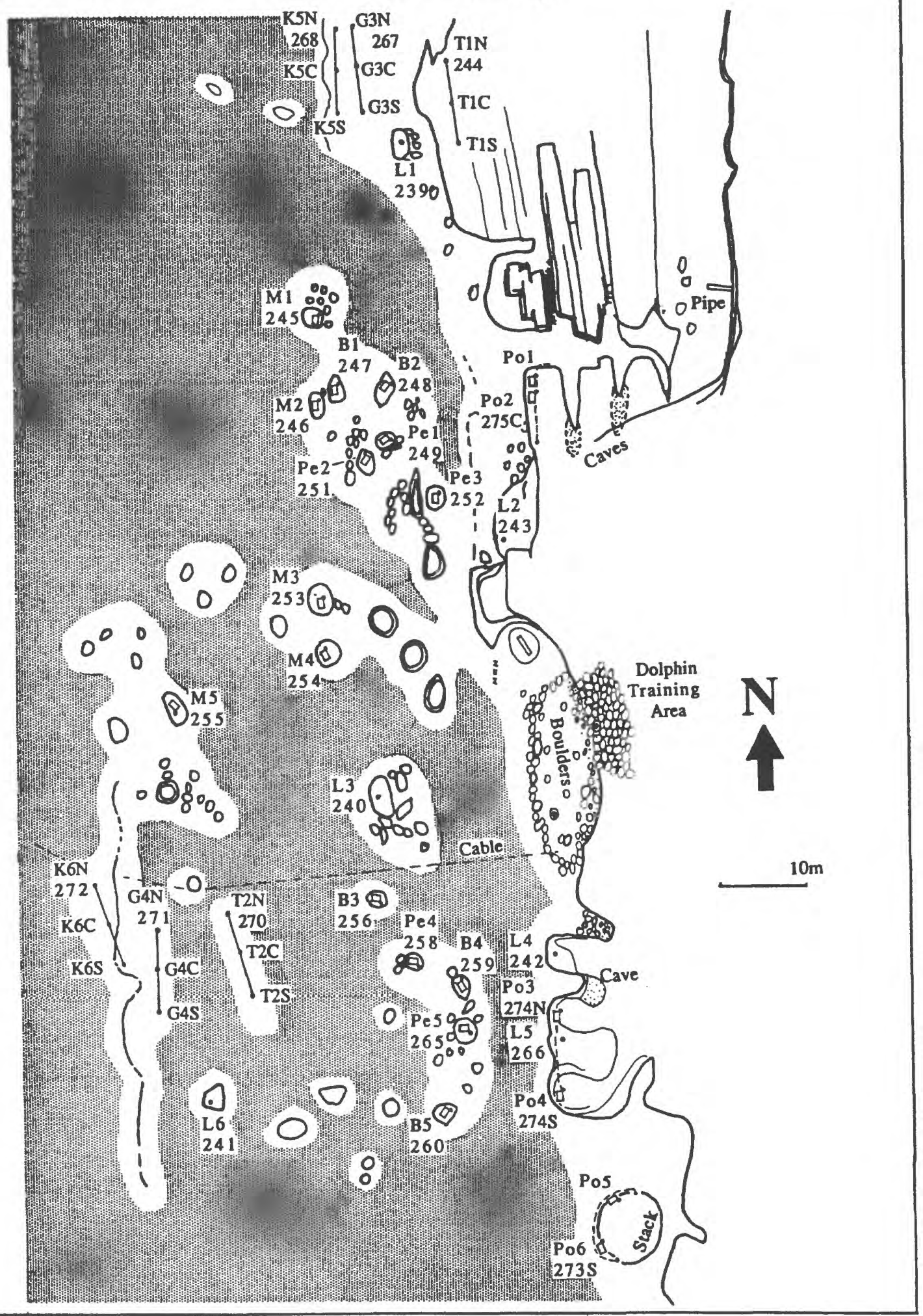




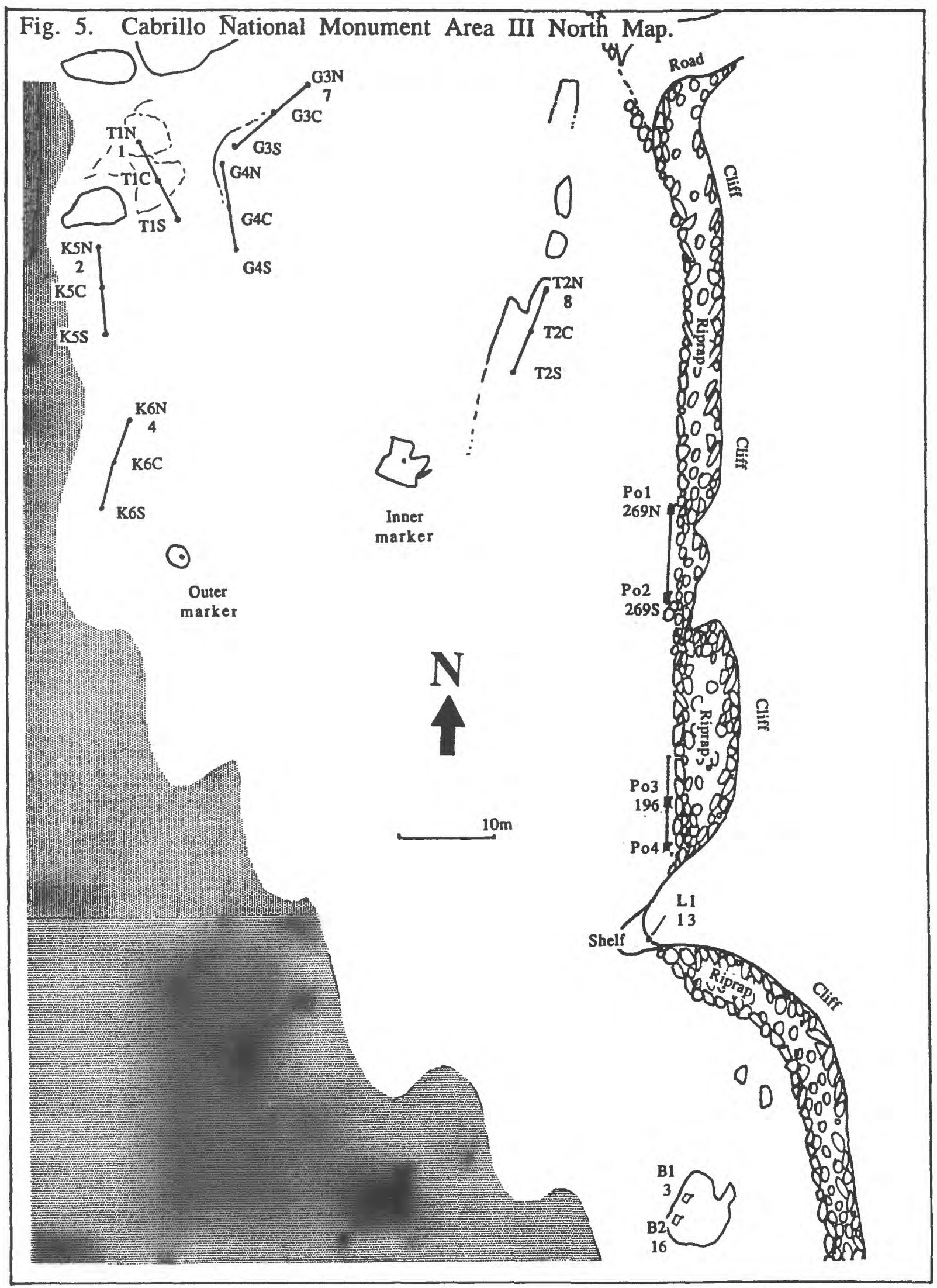


Fig. 6. Cabrillo National Monument Area III South Map.

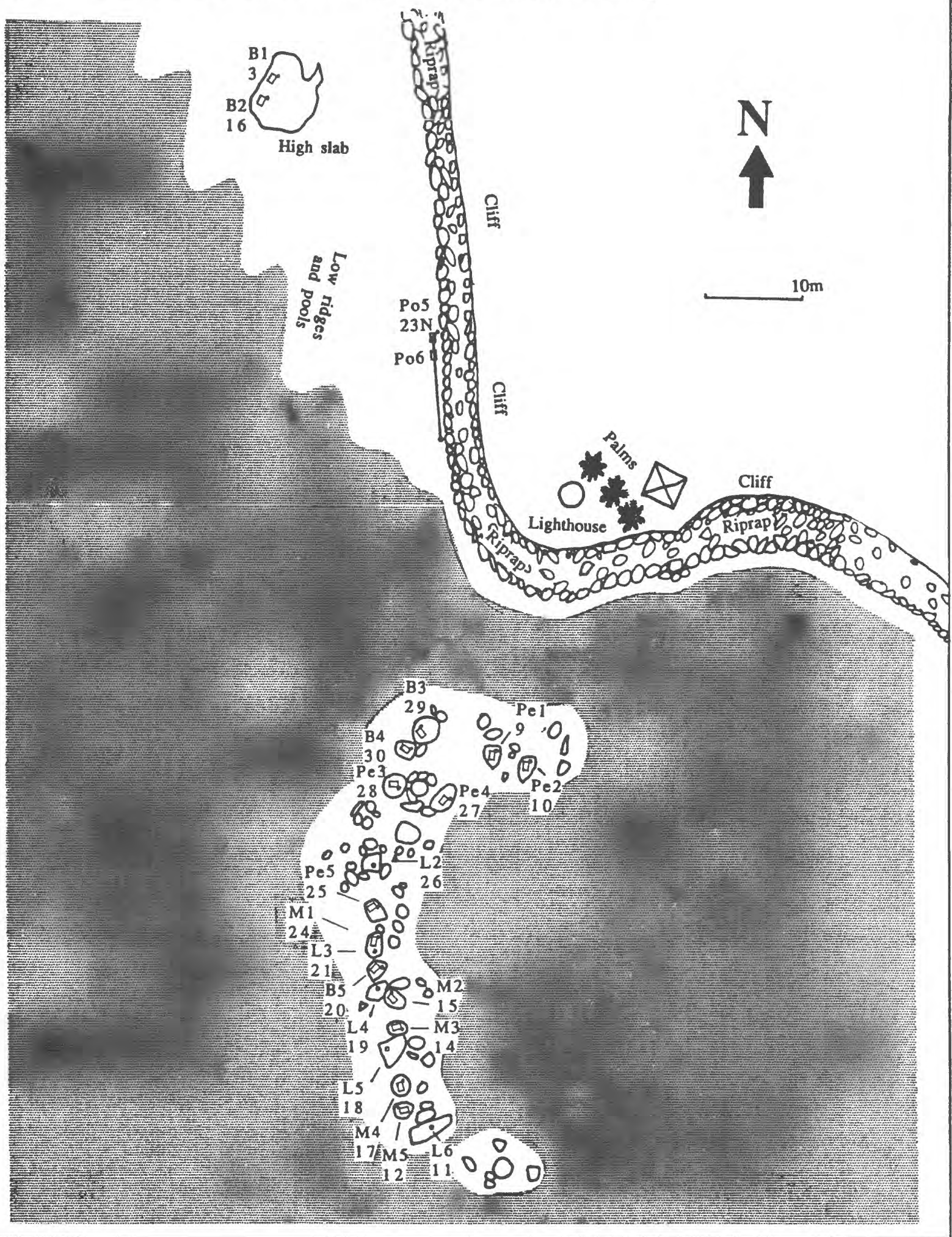


Figure 7. Photoplot Quadropod Apparatus
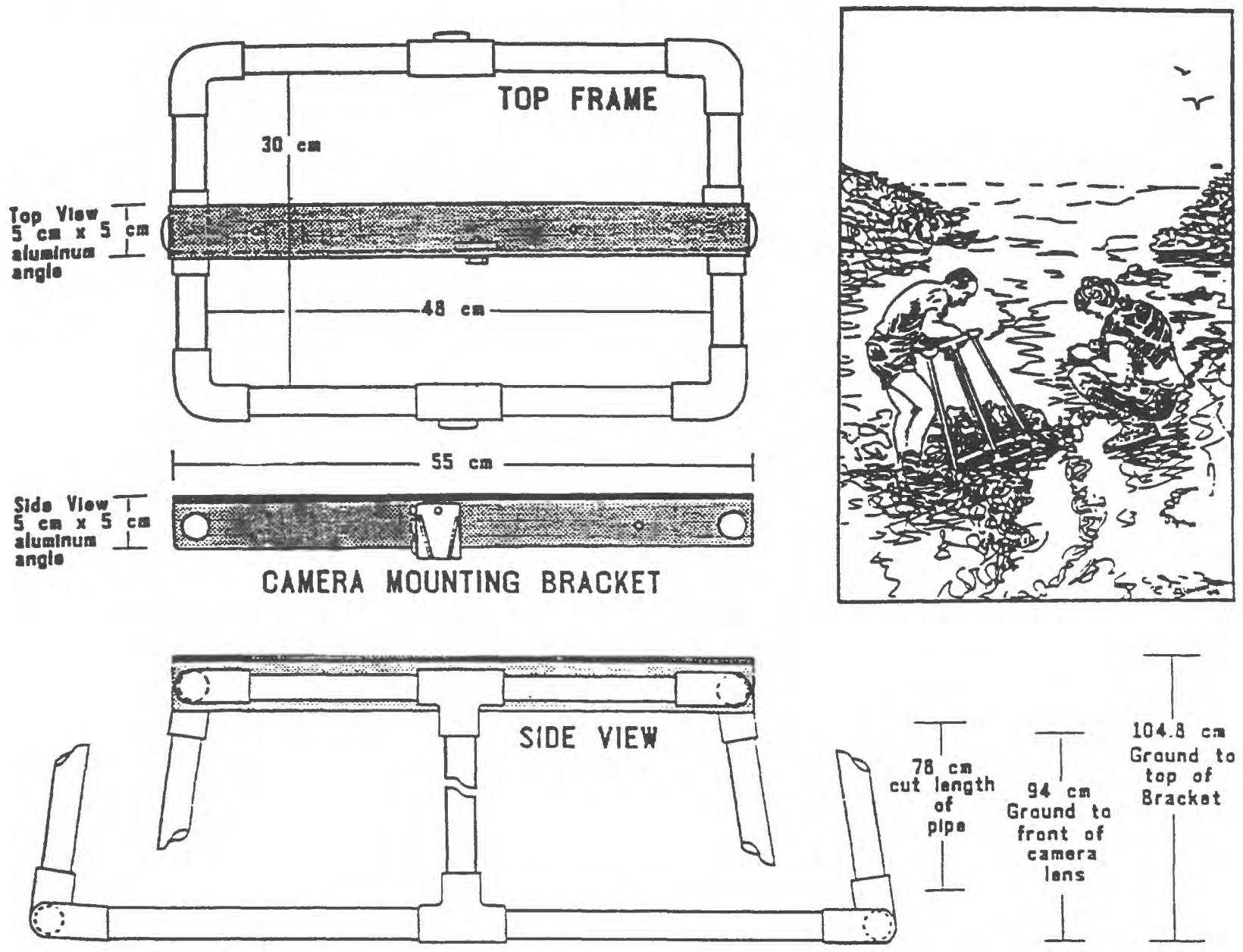

This example reads: \# 473

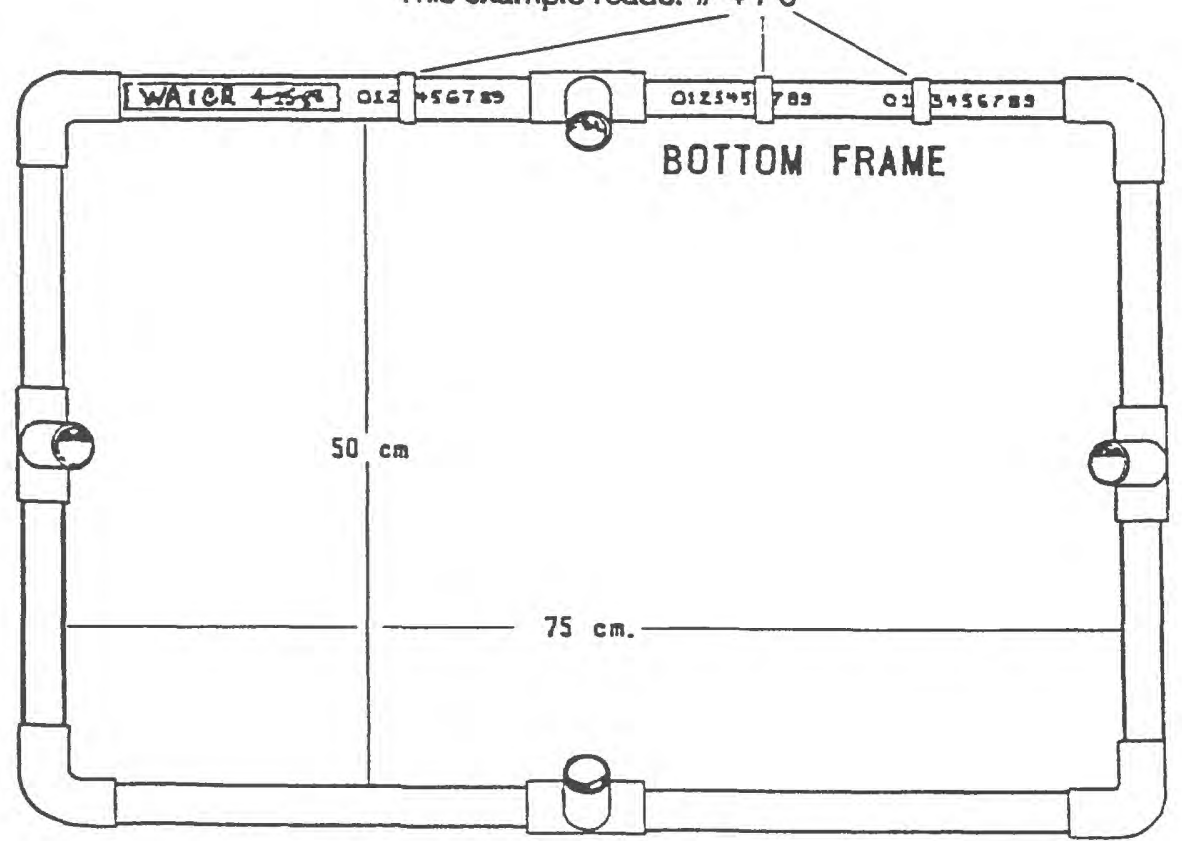

UST OF MATERIALS

1 each, $5 \mathrm{~cm} \times 5 \mathrm{~cm} \times 55 \mathrm{~cm}$ Aluminum $\mathrm{L}^{-}$ for camera mounting support

1 each, Quick Release Camera Mount

1" PVC PLASTIC PIPE. For Top Frame 4 each. Elbows 4 each, Ts 4 each, $12 \mathrm{~cm}$ pipes 4 each, $20 \mathrm{~cm}$ pipes For Bottorn Frame 4 each, Elbows 4 each, Ts

4 each, $23 \mathrm{~cm}$ pipes 4 each, $35 \mathrm{~cm}$ pipes For Legs

4 each, $78 \mathrm{~cm}$ pipes

For slip ring Indlcators 1 each. Union cut into 1 " pCs and sanded so as 10 slide on pipe frame. 
Form 1. Rocky Intertidal Interplot Measurements.

\begin{tabular}{|l|l|l|l|l|l|l|l|l|l|l|l|l|l|}
\hline From & To & Distance & Bearing & From & To & Distance & Bearing & From & To & Distance & Bearing \\
\hline & & & & & & & & & & & & & \\
\hline & & & & & & & & & & & & & \\
\hline & & & & & & & & & & & & & \\
\hline & & & & & & & & & & & & & \\
\hline & & & & & & & & & & & & & \\
\hline & & & & & & & & & & & & & \\
\hline & & & & & & & & & & & & & \\
\hline & & & & & & & & & & & & & \\
\hline & & & & & & & & & & & & & \\
\hline & & & & & & & & & & & & & \\
\hline & & & & & & & & & & & & & \\
\hline & & & & & & & & & & & & & \\
\hline & & & & & & & & & & & & & \\
\hline & & & & & & & & & & & & \\
\hline & & & & & & & & & & & & & \\
\hline & & & & & & & & & & & & & \\
\hline & & & & & & & & & & & & & \\
\hline & & & & & & & & & & & & \\
\hline & & & & & & & & & & & & & \\
\hline & & & & & & & & & & & & & \\
\hline
\end{tabular}


Form 2. Rocky Intertidal Survey Gear

\section{Documents}

\section{In NOTEBOOK/CLIPBOARDS}

\begin{tabular}{|l|l|}
\hline & Driver's licenses (carry on person) \\
\hline & CFG collecting permit (if collecting) \\
\hline & Intertidal Survey Handbooks (2) \\
\hline & \\
\hline
\end{tabular}

Site Information

\begin{tabular}{|l|l|}
\hline & Site Maps in plastic sleeves (3 sets) \\
\hline & Interplot Measurements in plastic sleeves (3 sets) \\
\hline & Field Notes from previous surveys (1 copy) \\
\hline & Print Photos of all plots/transects (1 set) \\
\hline & Clear Plastic Sheet Protectors (3 extra) \\
\hline
\end{tabular}

Data Forms

\begin{tabular}{|l|l|}
\hline & Field Log Forms (10) \\
\hline & Photo Log Forms (10 dbl sided) \\
\hline & Owl Limpet Forms (10 dbl sided) \\
\hline & Line Transect Forms (15 dbl sided) \\
\hline & Abalone/Sea Star Forms (5) \\
\hline & Bird/People Census Forms (5) \\
\hline
\end{tabular}

\section{Other}

\begin{tabular}{|l|l|}
\hline & $\# 2$ Pencils, sharpened (10) \\
\hline & Grease Pencil for notes on map overlays (1) \\
\hline & Tide Table (1) \\
\hline & Notepaper, (1 spare pad) \\
\hline & Large Rubber Bands for holding notes (5) \\
\hline & \\
\hline
\end{tabular}

\section{In BACKPACK or TOOLBOX}

\begin{tabular}{|l|l|}
\hline & Waterproof Compasses (2) \\
\hline & Bright Flagging Tape (2 rolls) \\
\hline & Small Waterproof Flashlight w/batteries (1) \\
\hline & Duct Tape (1 roll) \\
\hline & Cable Ties for repairs (a few in assorted sizes) \\
\hline & Waterproof Thermometer (1) \\
\hline & Splashzone Epoxy in 2 small tubs (1 set of A\&B) \\
\hline & Replacement Bolts, assorted lengths (10) \\
\hline & Bungee Cords or Velcro Straps (4) \\
\hline & Screwdrivers: normal and phillips (1 each) \\
\hline & Plastic Bags for specimen collection (optional) \\
\hline & Small Plastic Specimen Vials (optional) \\
\hline & Metric Calipers for measuring limpets (3) \\
\hline & Yellow Crayons for marking limpets (5) \\
\hline 1 m Lines or Tapes for limpet plots (3) \\
\hline Wire Brushes/ Knives to clean markers (3 each) \\
\hline \\
\hline
\end{tabular}

OTHER ITEMS

\begin{tabular}{|l|l|}
\hline & PVC Photo Quadrapod Apparatus (1) \\
\hline & PVC Quadrats for marking plots (5-15) \\
\hline & $\begin{array}{c}\text { Meter Tapes: 30 m for marking transects (6) } \\
60 \text { or 100 m for measurements (1) }\end{array}$ \\
\hline & Backpacks/Buckets to hold loose items (several) \\
\hline & Aluminum Clipboards (4) \\
\hline & Foam kneeling pads (3) \\
\hline & First Aid Kit (1) \\
\hline & Portable Drill, Bits, Batteries or Fuel (optional) \\
\hline & Rock Hammer (optional) \\
\hline & Bright Flag Sticks to mark plots (optional) \\
\hline & Orange cones (optional) \\
\hline & Species Identification Books (optional) \\
\hline
\end{tabular}

\section{In CAMERA CASE}

\begin{tabular}{|l|l|}
\hline & Camera and Lens (1) (tested) \\
\hline & Strobe (1) (tested) and synch. cord \\
\hline & Batteries for strobe (plus spare) \\
\hline & $\begin{array}{l}\text { Color Slide Film: 36 exposure, 100 ASA, } \\
\text { Ektachrome or equivalent (3??? rolls) }\end{array}$ \\
\hline & Lens Cap, Paper, and Cleaning Fluid (1 each) \\
\hline & Waterproof Marking Pen (1) \\
\hline & Bolt for camera/quadrapod mount (1 spare) \\
\hline & Crescent Wrench for camera mount (1) \\
\hline & Camera and Strobe manuals (1 each) \\
\hline & \\
\hline & \\
\hline
\end{tabular}

\section{In VIDEO CASE (optional)}

\begin{tabular}{|l|l|}
\hline & Video Camcorder in Plastic Housing (1) (tested) \\
\hline & Hi or Reg 8 mm 1 hr videotapes (1 plus 1 spare) \\
\hline & Video Battery Packs (2 heavy duty) (charged) \\
\hline & Lens Paper and Cleaning Fluid (1 each) \\
\hline & Desiccant Packs (3 small) \\
\hline & Head-Cleaning Cassette (1) \\
\hline & Small Towel (1) \\
\hline & Video Camcorder Manual (1) \\
\hline & Camcorder Date/Time Disk Battery (1 spare) \\
\hline & Headphone to check sound (1) \\
\hline & \\
\hline
\end{tabular}

\section{PERSONAL GEAR}

\begin{tabular}{|l|l|}
\hline & Intertidal Shoes, Boots, or Booties \\
\hline & Windbreaker and Foul Weather Gear \\
\hline & Spare Dry Clothing \\
\hline & Hat, Sunglasses, and Sunscreen \\
\hline & Snack Food and Drink \\
\hline & Daypack \\
\hline & Wetsuit, Kneepads, Gloves (optional) \\
\hline & \\
\hline & \\
\hline & \\
\hline
\end{tabular}


Form 3: ROCKY INTERTIDAL MONITORING FIELD LOG

Date: Time:

Page: of

Study Site:

Participants:

Recorder:

Temperature: Air ${ }^{\circ} \mathrm{C}$ Water ${ }^{\circ} \mathrm{C}$ Tide Level (ft) Wind: Speed (kt) Direction Cloud Cover $\%$

Wave Height (ft) Surge (light, moderate, heavy)

Field Log (General account of intertidal work, including observations and sketches): 
Form 4: ROCKY INTERTIDAL MONITORING PHOTO LOG

Date:

Area:

Photographer:

Recorder:
Page: Film Roll \#:

\begin{tabular}{|c|c|c|c|c|c||}
\hline $\begin{array}{c}\text { Photo } \\
\#\end{array}$ & $\begin{array}{c}\text { Study } \\
\text { Site }\end{array}$ & $\begin{array}{c}\text { Quadrat } \\
\#\end{array}$ & $\begin{array}{c}\text { Shutter } \\
\text { Speed }\end{array}$ & F/Stop & \\
\hline 1 & & & & & \\
\hline 2 & & & & & \\
\hline 3 & & & & & \\
\hline 4 & & & & & \\
\hline 5 & & & & & \\
\hline 6 & & & & & \\
\hline 7 & & & & & \\
\hline 8 & & & & & \\
\hline 9 & & & & & \\
\hline 10 & & & & & \\
\hline 11 & & & & & \\
\hline 12 & & & & & \\
\hline 13 & & & & & \\
\hline 14 & & & & & \\
\hline 15 & & & & & \\
\hline 16 & & & & & \\
\hline 17 & & & & & \\
\hline 18 & & & & & \\
\hline 19 & & & & & \\
\hline 20 & & & & & \\
\hline 21 & & & & & \\
\hline 22 & & & & & \\
\hline 23 & & & & & \\
\hline 24 & & & & & \\
\hline 25 & & & & & \\
\hline 26 & & & & & \\
\hline 27 & & & & & \\
\hline 28 & & & & & \\
\hline 29 & & & & & \\
\hline 30 & & & & & \\
\hline 31 & & & & & \\
\hline 32 & & & & & \\
\hline 33 & & & & & \\
\hline 34 & & & & & \\
\hline 35 & & & & & \\
\hline 36 & & & & & \\
\hline 38 & & & & & \\
\hline
\end{tabular}


Form 5: ROCKY INTERTIDAL OWL LIMPET MEASUREMENTS

Date:

Study Site:

Recorder:

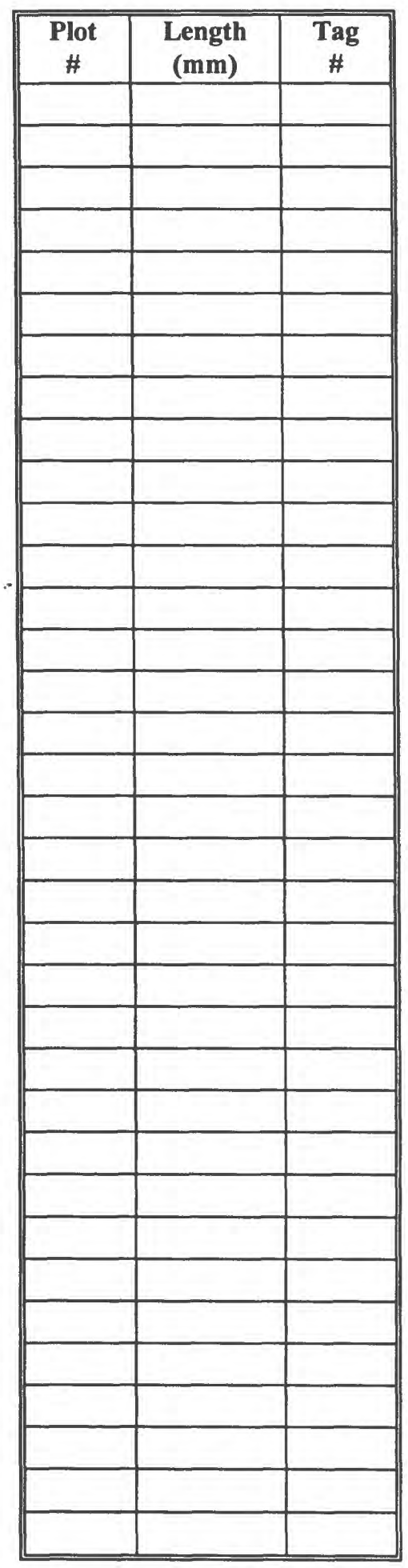

Page: of Measurer
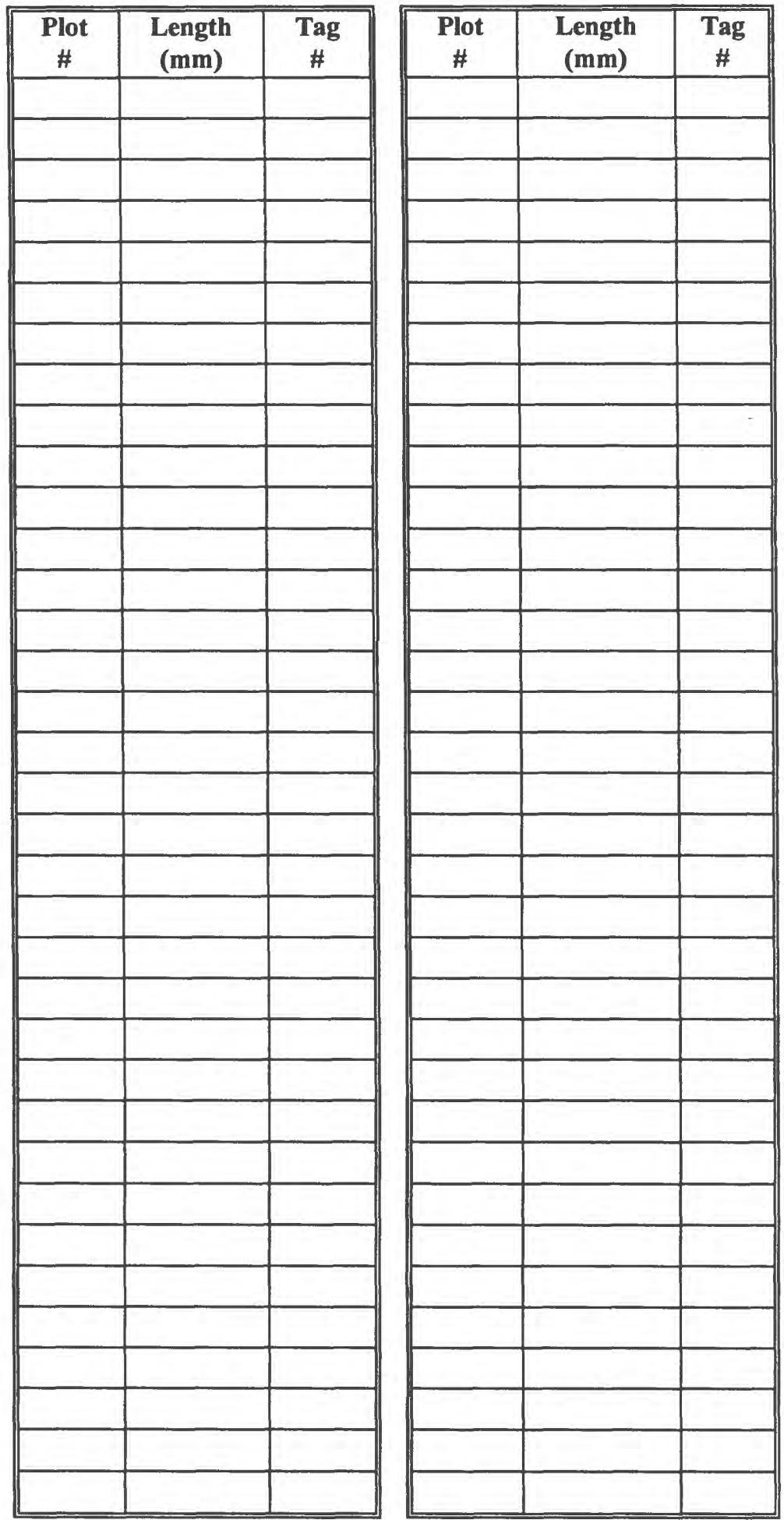
Form 6. ROCKY INTERTIDAL MONITORING LINE-INTERCEPT TRANSECT

Location:

Recorder:

Cover:
Transect \#:

Date:

Reader:

Distance Along Transect (cm):
Boa Kelp

Egregia sp.

Sargassum Weed

Sargassum

Red Algal Turf

Corallina sp., et al.

Total:

Total:

Total:

Total:

Surf Grass

Phyllospadix sp.

Aggregating Anemone

Total:

Anthopleura elegantissima

Other Biota

Tar

Bare Substrate

Total:

Total:

Total:
Comments: 


\section{Form 7. ROCKY INTERTIDAL ABALONE/SEA STAR COUNTS}

\begin{tabular}{|c|c|c|c|}
\hline Date: & Time: & Site: & Recorder: \\
\hline SPECIES & $\#$ & *Size $(\mathrm{cm})$ & Notes (shells, condition, location, etc...) \\
\hline \multicolumn{4}{|l|}{ Black Abalone } \\
\hline \multicolumn{4}{|l|}{ Green Abalone } \\
\hline \multicolumn{4}{|l|}{ Pink Abalone } \\
\hline \multicolumn{4}{|l|}{ Ochre Sea Star } \\
\hline \multicolumn{4}{|l|}{ Blue Sea Star } \\
\hline \multicolumn{4}{|l|}{ Bat Star } \\
\hline \multicolumn{4}{|l|}{ Fragile Star } \\
\hline Other_ & & & \\
\hline
\end{tabular}

\begin{tabular}{|c|c|c|c|}
\hline Date: & Time & Site: & Recorder: \\
\hline SPECIES & \# & *Size $(\mathrm{cm})$ & Notes (shells, condition, location, etc...) \\
\hline \multicolumn{4}{|c|}{ Black Abalone } \\
\hline \multicolumn{4}{|c|}{ Green Abalone } \\
\hline \multicolumn{4}{|l|}{ Pink Abalone } \\
\hline \multicolumn{4}{|c|}{ Ochre Sea Star } \\
\hline \multicolumn{4}{|l|}{ Blue Sea Star } \\
\hline \multicolumn{4}{|l|}{ Bat Star } \\
\hline \multicolumn{4}{|l|}{ Fragile Star } \\
\hline Other & & & \\
\hline
\end{tabular}

\begin{tabular}{|c|c|c|c|}
\hline Date: & Time: & Site: & Recorder: \\
\hline SPECIES & $\#$ & *Size $(\mathrm{cm})$ & Notes (shells, condition, location, etc...) \\
\hline \multicolumn{4}{|l|}{ Black Abalone } \\
\hline \multicolumn{4}{|c|}{ Green Abalone } \\
\hline \multicolumn{4}{|l|}{ Pink Abalone } \\
\hline \multicolumn{4}{|l|}{ Ochre Sea Star } \\
\hline \multicolumn{4}{|l|}{ Blue Sea Star } \\
\hline \multicolumn{4}{|l|}{ Bat Star } \\
\hline \multicolumn{4}{|l|}{ Fragile Star } \\
\hline Other & & & \\
\hline
\end{tabular}

*For abalone, measure greatest shell length. For sea stars, measure from center of disk to tip of longest ray. 
Form 8. ROCKY INTERTIDAL PEOPLE AND BIRD CENSUS

Date:

Time:

Page \#:

Study Site:

Observer:

Temperature: Air

Wind: Speed (kt)

Low Tide Level: (ft)

${ }^{\circ} \mathrm{C}$ Water

Direction at (time)

${ }^{\circ} \mathrm{C}$ Wave height: (ft) Cloud Cover:

\begin{tabular}{|l|l|l|l||}
\hline & AREA III & AREA II & AREA I \\
\hline People & & & \\
\hline Wading Birds & & & \\
Great Blue Heron & & & \\
\hline Great Egret & & & \\
\hline Snowy Egret & & & \\
\hline Other & & & \\
\hline Shore Birds & & & \\
\hline Black-bellied Plover & & & \\
\hline Willet & & & \\
\hline Wandering Tattler & & & \\
\hline Spotted Godwit & & & \\
\hline Whimbrel & & & \\
\hline Ruddy Turnstone & & & \\
\hline Sanderling & & & \\
\hline Other & & & \\
\hline Gulls & & & \\
\hline Western & & & \\
\hline California & & & \\
\hline Heermann's & & & \\
\hline Mew & & & \\
\hline Ring-billed & & & \\
\hline Other & & & \\
\hline & & & \\
\hline
\end{tabular}


Form 9. ROCKY INTERTIDAL MONITORING PHOTO POINT INTERCEPT FORM

Site

Scored by

\begin{tabular}{|l|l|l|l|l|l|}
\hline BARNACLE PLOT \# & & & & & \\
\hline Total Points & & & & & \\
\hline Acorn Barnacle & & & & & \\
\hline Thatched Barnacle & & & & & \\
\hline Rockweed & & & & & \\
\hline California Mussel & & & & & \\
\hline Goose Barnacle & & & & & \\
\hline Other Plant & & & & & \\
\hline Other Animal & & & & & \\
\hline Bare Substrate & & & & & \\
\hline Tar & & & & & \\
\hline
\end{tabular}

Survey Date

Score Date
ROCKWEED PLOT\#

Total Points

Acorn Barnacle

Thatched Barnacle

Rockweed

California Mussel

Goose Barnacle

Other Plant

Other Animal

Bare Substrate

Tar

\begin{tabular}{|l|l|l|l|l|l|}
\hline MUSSEL PLOT\# & & & & & \\
\hline Total Points & & & & & \\
\hline Acorn Barnacle & & & & & \\
\hline Thatched Barnacle & & & & & \\
\hline Rockweed & & & & & \\
\hline California Mussel & & & & & \\
\hline Goose Barnacle & & & & & \\
\hline Other Plant & & & & & \\
\hline Other Animal & & & & & \\
\hline Bare Substrate & & & & & \\
\hline Tar & & & & & \\
\hline
\end{tabular}

\begin{tabular}{|l|l|l|l|l|l|l|}
\hline POLLICIPES PLOT \# & & & & & & \\
\hline Total Points & & & & & & \\
\hline Acorn Barnacle & & & & & & \\
\hline Thatched Barnacle & & & & & & \\
\hline Rockweed & & & & & & \\
\hline California Mussel & & & & & & \\
\hline Goose Barnacle & & & & & & \\
\hline Other Plant & & & & & & \\
\hline Other Animal & & & & & & \\
\hline Bare Substrate & & & & & & \\
\hline Tar & & & & & & \\
\hline
\end{tabular}

